Portland State University

PDXScholar

Fall 12-21-2016

\title{
Manufacturing Consent in the Maghreb: How Mohammed VI of Morocco Survived the Arab Spring
}

David Michael Duke II

Portland State University

Follow this and additional works at: https://pdxscholar.library.pdx.edu/open_access_etds

Part of the African Studies Commons, and the Political Science Commons Let us know how access to this document benefits you.

\section{Recommended Citation}

Duke II, David Michael, "Manufacturing Consent in the Maghreb: How Mohammed VI of Morocco Survived the Arab Spring" (2016). Dissertations and Theses. Paper 3413.

https://doi.org/10.15760/etd.5311

This Thesis is brought to you for free and open access. It has been accepted for inclusion in Dissertations and Theses by an authorized administrator of PDXScholar. Please contact us if we can make this document more accessible: pdxscholar@pdx.edu. 
Manufacturing Consent in the Maghreb:

How Mohammed VI of Morocco Survived the Arab Spring

by

David Michael Duke II

A thesis submitted in partial fulfillment of the requirements for the degree of

Master of Arts

in

Political Science

Thesis Committee:

Lindsay J. Benstead, Chair

David Kinsella

Joshua C. Eastin

Portland State University

2016 
(C) 2016 David Michael Duke II 


\begin{abstract}
The Arab Spring of 2011 revealed stark variation in the durability of different types of authoritarian regimes. Kings and emirs demonstrably outperformed their republican peers. This paper provides a qualitative study of the Moroccan monarchy in order to better explain this pattern. The findings of an original media content analysis support the paper's thesis that Morocco's King Mohammed VI maintained his throne by effectively using a historically derived position of concentrated power and immense wealth to manipulate potential opposition and dominate public discourse. This multicausal mechanism of manufactured consent helped create and sustain the monarch's domestic legitimacy while alienating his opponents. Importantly, the illusion of a free media bolsters his image with Western political elites, thus, drawing greater external support and reducing the cost of repression.
\end{abstract}




\section{Dedication}

This thesis humbly pays tribute to those throughout the Middle East and North Africa who have long struggled for dignity and freedom and continue to do so. 


\section{Acknowledgements}

First and foremost, I owe tremendous gratitude to my advisor, Lindsay Benstead, for her great patience and guidance through a much protracted thesis writing process. Moreover, as her graduate assistant for two years, I learned much about moderating contentious undergraduate discourse as well as grading papers. I would also like to thank the other members of my committee, David Kinsella and Joshua Eastin, for their attention to detail and commentary which have helped make this a far better product.

David Kinsella, Lindsay Benstead and Yasmine Hanoosh played no small role in writing recommendations on my behalf for various scholarships and fellowships which made this research possible. These included two Foreign Language and Area Studies fellowships (one in Tunisia), a Critical Language Scholarship for Arabic in Jordan, and most importantly, a one year Boren Fellowship for research and Arabic study in Morocco - the inspiration and vehicle for this thesis. Professor Hanoosh's great patience and skill are largely responsible for my Modern Standard Arabic language acquisition.

Overseas, instructors at Qalam wa Lawh in Rabat and teachers at Qasid Arabic Institute of Amman were unbelievably kind and generous while teaching me their local dialects. Their humor, intelligence and openness have given me a personal connection to the region and an awareness of its diversity which makes oversimplification of its political and cultural struggles virtually impossible. The defects in my employment of the Arabic language and its dialects are solely my responsibility. Seloua Zerhouni and Badr Eddine of Mohammed V University in Rabat showed great hospitality giving me access 
to their research and resources. Thanks are also owed to Siham Kanba who kindly edited English translations of interviews conducted in Arabic.

Birol Yesilida and Tugrul Keskin, along with the Middle East Studies Center, broadened my perspective of the greater Middle East, in part, by facilitating my acceptance into a unique academic and cultural excursion to Turkey in 2012. I have truly been very fortunate for all of these academic opportunities.

Finally, I would like to thank my family for their love, support, and encouragement while I ventured abroad in the Middle East living and learning. This journey could not have happened without them. I should also acknowledge my two shorthair cat friends, Maynard and Vincent, who accompanied me to Morocco and Tunisia; suffering the travails of overseas flying, foreign bugs, and the inquisitiveness of people more accustomed to cats on streets than in enclosures. 


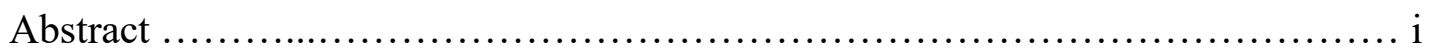

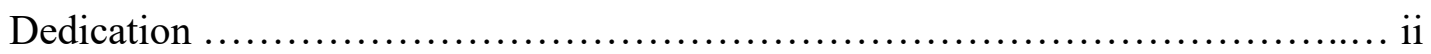

Acknowledgements ................................................. iii

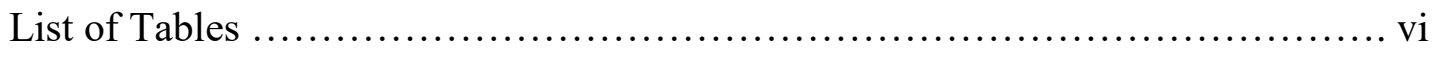

Chapter 1

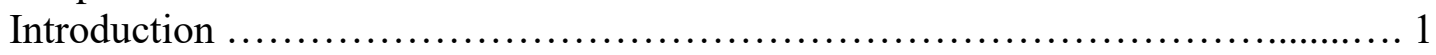

Chapter 2

Typology of Regimes in North Africa ............................................ 5

Chapter 3

Review of Monarchical Resilience Literature ................................. 12

Chapter 4

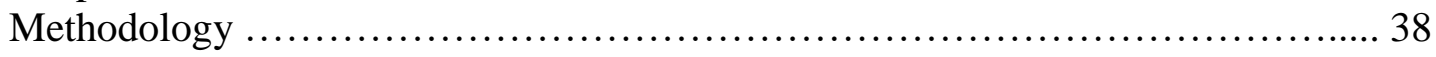

Chapter 5

Results ............................................................... 43

Chapter 6

Analysis of the Moroccan Arab Spring ...................................... 50

Chapter 7

Impact of Mechanisms on Jordan ....................................... 82

Chapter 8

Implications for U.S. Foreign Policy ..................................... 90

Chapter 9

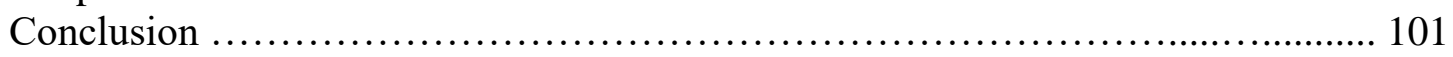

References ......................................................... 103

Appendices

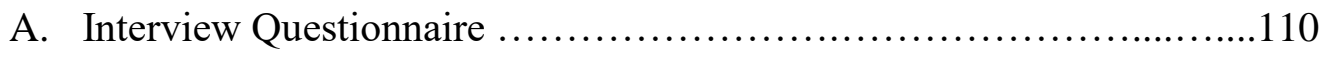

B. Media Content Analysis Data (Discourse Analysis)....................111 


\section{List of Tables}

Table 1: Print Media Content Quantitative Summary .............................. 43 


\section{Chapter 1}

Introduction

The aftermath of the Arab Spring suggests that Middle East monarchies are inherently more stable than their republican counterparts. Four republican leaders have abdicated power since December 2010 when a fruit vendor in Tunisia initiated a regional wave of social and political upheaval. Not one of the eight Arab monarchs has been removed from his throne during this time. This outcome is particularly interesting because it defies scholarship anticipating the demise of monarchical rule. ${ }^{1}$ Instead, these royal regimes remain robust through the upheaval of the last half-decade.

A line of academic inquiry addresses the nature of this monarchy/republic performance gap by examining the veracity of the idea that monarchies possess intrinsic advantage owing to their institutional design. What is evident from this literature is that the persistence of monarchy cannot be attributed to any one single factor and that regime type has yet to be excluded as a potential explanation. Understanding precisely how individual monarchies have weathered recent social unrest by examining their unique path dependent histories will contribute to understanding this "gap" and to addressing the persistence of authoritarian regimes generally. A qualitative case study of Morocco is presented here in contribution to this ongoing debate on the durability of monarchy. It incorporates an original Arabic print media content analysis (MCA) of over 30 Moroccan newspapers collected over six months in 2013. Given that monarchies outperformed their

\footnotetext{
1 (Huntington 2006) Huntington's "king's dilemma" presaged the decline of absolute monarchy as a political institution in the 1970s. Notably, he remarked Morocco (and Afghanistan) were the most likely to
} survive the modernization process. 
republican counterparts in withstanding the protests and conflict of the Arab Spring, does Morocco's form of government explain its resiliency?

This thesis contends that Mohammed VI maintained power during the Arab Spring through a system of manufactured consent facilitated by its monarchical regime type: a system predicated upon concentrated decision-making authority and wealth, which both allowed it to coopt Islamist opposition and discredited secular opposition through its monopoly over public discourse on reform.

The Moroccan monarchy maintains political stability (or more accurately, enforces political hegemony) by effectively employing three "mechanisms of monarchy." These are economic, political, and normative mechanisms which enable the regime to maintain power. ${ }^{2}$ As leader of the Makhzan, ${ }^{3}$ Mohammed VI (or M6) is a billionaire whose holdings play the single largest role in guiding the state's neo-colonial development. He sits atop a centuries-old patronage system; as head of state, he is a policy reformer and arbiter among political parties who possesses final authority over parliamentary legislation. As the unifying and legitimizing symbol of nationhood, he is Commander of the Faithful — a leader who infuses religious and nationalistic narratives with symbolism in order to maintain his legitimacy as an unassailable authority.

During the Arab Spring, the nearly 350 year old Alawi ruling dynasty of Morocco, called upon this system of manufactured consent: a historically derived position of economic wealth and political preeminence to dominate a public zeitgeist for

\footnotetext{
2 (Lucas 2014) Lucas classifies these mechanisms as distribution of decision-making power, distribution of economic resources, and distribution of cultural norms. For simplicity, this paper may use alternative or abbreviated terms, but their meanings are essentially the same.

${ }^{3}$ Makhzan is an Arabic term referring to a storehouse. The term is now colloquially used in Morocco to denote the King and his coterie of supporters who manage the state's wealth.
} 
reform. This paper argues that the durability of the Moroccan monarchy has less to do with preference for a regime type, per say, than it does with the ability of entrenched power to manipulate the public discourse and convince a critical mass that it represents whatever form of legitimacy they identify with. Thus, the more effective the regime is at conveying its message, the less it relies on repression, conferring upon the regime a perception of legitimacy both domestically and internationally.

Findings from the original MCA in this paper reveal that the Moroccan media projects an overwhelmingly positive image of the monarchy while the Islamist opposition party is nearly always depicted as embattled and impotent. These results align with the institutional hypothesis that the monarchy has both the economic resources and political power to dominate the media sphere. The MCA findings reveal certain limitations of institutional media manipulation which do offer limited openings for opposition voices, but more importantly, give the illusion of a free media to many non-elites in Morocco as well as international political elites.

His status as religious and nationalist leader does afford the king legitimacy, but it is position as head of the Makhzan which ultimately gives him the greatest power. Not surprisingly, this role is not codified in the constitution nor is it openly discussed in Moroccan media. This paper demonstrates how deft manipulation of a historically derived mechanism of control based on immense wealth and manufactured sharifian prestige, enabled the king to dominate the public discourse during the Arab Spring by obfuscating the media-scape and presenting himself as the nation's lead reformer, ultimately allowing him to coopt political Islamists and discredit secular modernizing opposition. 
Chapter 2 defines the concept of regime and surveys North African regime types. A review of MENA authoritarian resistance scholarship is follows in the subsequent chapter. This review begins with background information on previous explanations for regime durability but focuses on contemporary explanations for the stability of MENA monarchies and non-monarchies including: institutional, geostrategic, repression, legitimacy, economic and synthetic theories.

The methodology section (Chapter 4) presents the socio-institutional analytical framework to be employed along with a description of the three mechanisms of monarchism adapted from Lucas's hybrid New Institutional/Social Movement Theory (NI/SMT). An overview of sources and data types collected during field research will also be included for this primarily qualitative project. Original research results are presented in Chapter 4 which incorporate a print media content analysis and a formal interview conducted in Arabic with a Moroccan professor of politics based in Fez.

The discussion section (Chapter 5) critically examines the case of the Alawi regime throughout the most recent Arab Awakening by examination of the three mechanisms of monarchy: the distribution of decision-making power, the distribution of economic resources, and the distribution of cultural norms. Selective comparisons to republican states throughout this discussion will assist in defining and differentiating Morocco's monarchy. This explanatory model is then applied summarily in Chapter 6 to the case of Jordan, the most institutionally similar MENA regime, to assess its potential for future detailed analysis. Thoughts for U.S. foreign policy stakeholders are considered in Chapter 7. A final chapter concludes this thesis. 


\section{Chapter 2}

\section{Typology of Regimes in North Africa}

This chapter provides a typological treatment of North African regimes in order to facilitate the fruitful assessment of the impact of regime type on monarchical resilience. This chapter begins with consideration of the concept of regime and follows with a comparison of the various regime types in North Africa. Unpacking the often oversimplified depiction of what constitutes monarchies and republics facilitates a more accurate explanation of what has helped Mohammad VI to maintain his throne.

It is simplest to think of a regime as the key power holders within a state. A more explicit definition of regime is "a group of actors who successfully enforce their claim to power at the top of the power pyramid and maintain their position through formal and informal mechanisms (such as clientelism and patronage) that are both vertical and occasionally horizontal in their ties to relevant factions/elites within the ruling elite." 4 Though most attention is usually given the singular figure known as the head of state, the coterie of elites which surround this person are often at least as influential over state functions. Peering beneath the veneer of the traditional republican/monarchy dyad reveals a diverse, and more analytically fruitful, taxonomy.

A more precise definition comes from Ellen Lust. She defines a regime as "the set of formal and informal rules (institutions) that are used to select leaders and policies, and thus, determine how efficiently and for whose benefit, resources are used." 5 This

${ }^{4}$ (Derichs 2014, 182)

${ }^{5}$ (Lust 2011, 152) 
definition is particularly useful here. As Lust states, using "regime" simply as a reference to an individual or group in power neglects the continuity inherent in a particular political structure even when an alternation in power occurs. Egypt is an excellent example of how focusing on one individual loses the context of control inherent in a larger political structure.

Both Egypt and Algeria have had military regimes for decades. The Supreme Council of the Armed Forces (SCAF) remains the preeminent political power in Egypt, having been so since Nasser's coup against King Farouk in 1952. Though Mubarak was deposed in 2011, the SCAF remained intact, and was instrumental in removing his popularly elected successor, Mohamed Morsi - a Muslim Brother. Al-Akhawayn, or the Muslim Brotherhood, is a social and religious network which has long been a popular rival to Egypt's generals. Now that General el-Sisi is acting as president, this republic's leadership is now truly sans vetements. As a regime type, the distribution of power, both politically and economically, is dispersed among a cadre of elite military personnel. The Egyptian case, despite treatments to the contrary in scholarly literature, better demonstrates the continuity of regime through the Arab Spring. The generals still call the shots.

Algerians, likewise, endure the presence of a military-revolutionary regime popularly known as the Pouvoir. Abdelaziz Bouteflika, a co-founder of Algerian independence, has been president since 1999, despite long absences due to treatments for health issues in Europe. The skill with which the Pouvoir's regime incumbents have 
manipulated elections to maintain the appearance of democracy is well documented. ${ }^{6}$ Still, Algeria has weathered immense violence and bloodshed since independence in 1963 in the name of authentic democracy. The 1990s witnessed the deaths of close to one million following the region's first democratically elected Islamist party. The Pouvoir saw the Islamists as a threat to its position of power, and was able to marshal domestic and international support for its struggle against the popular Islamists. Since the turn of the century, Algeria has remained largely at peace. Relying on the country's immense gas reserves, and Western military aid in its fight against terrorism in the Global War on Terror (GWOT), the Pouvoir manages to contain the super-heated social forces beneath a thin electoral façade and cash pay outs. Though Algeria has survived the Arab Spring, one can only speculate when the money from Sonatrach (the state-owned hydrocarbon exploration company) and international support will become insufficient to contain the tidal social forces in this war-weary state.

Colonel Muammar Qaddafi, in emulation of Egypt's Abdel Nasser, led a military coup against King Idris of Libya in 1969. The Arab Libyan Republic soon turned into one of the world's most eccentrically personalist regimes. The "Brother Colonel" penned the iconic Green Book which detailed his vision of a true people's democracy. Despite these democratic precepts, Qaddafi was a dictator who tightly controlled three fractious regions, Cyrenaica, Tripolitania, and the Fezzan, largely by using the state's vast oil reserves of "clean oil" to pay off a foreign mercenary security force and to distribute patronage. While domestic opposition was kept at bay through coercion and huge monetary pay-outs for decades, it was the international sphere where the Colonel faced

${ }^{6}$ (Tessler 2011; Lust 2011) 
his gravest threats. In 1986, Qaddafi survived a missile strike ordered by Ronald Reagan, in retaliation for the Libyan leader's connection to a Berlin discotheque bombing. Qaddafi's alliance with the Soviet bloc, Pan-Arab socialism, anti-Israel policies, support for terrorism in Palestine, and search for uranium in Chad (for production of nuclear capabilities) made him a marked man. For all these reasons, the U.S. administration wanted regime change in Libya. Despite missing the main target in 1986, Qaddafi's stepdaughter and scores of supporters were killed. Regime change in Libya was postponed until 2011, when NATO-led military forces effectively gave Libyan regime opposition the upper hand in the country's post-Arab Spring civil war. As a regime type, one can hardly imagine a more singular reign than that of Colonel Qaddafi by any person with a crown. Even though his domestic legitimacy was relatively weak, being borne by oil revenue and force, his eventual demise was largely enabled by external forces. The Libyan case reminds how effective oil rentierism is at subjugating a citizenry.

Tunisia initiated the Arab Spring, and after five years, it is the only MENA state to have emplaced a new government with real constitutional authority, and then undertaken a peaceful democratic alternation in power. The republic seemed to have a lot going for it long before 2011: a strong diversified economy; secular leadership facing little opposition from entrenched Islamic groups; a homogenous, well-educated population; and relatively small land mass unencumbered by mountains which are notorious for sheltering regime opposition groups. ${ }^{7}$ Lacking hydrocarbons, Tunisia has a diversified manufacturing sector and has relied on its natural beauty and cosmopolitan

\footnotetext{
${ }^{7}$ Not that Ennadha and other Islamists didn't exist, rather, the secularizing founder of the modern state, Habib Bourguiba, had done an extraordinary job of consolidating power in the vein of Kemal Ataturk.
} 
charm for tourist revenue. Ben Ali took over the presidency from Habib Bourguiba in a "medical coup" in 1986. The charisma, strength, and inherent legitimacy of Bourguiba gone, Ben Ali doubled down on repression against dissent and promulgation of neoliberal economic policies to fund his regime. With the assistance of his wife, Leila Trabelsi, they leveraged state revenues within international markets and drew in very healthy returns. What Tunisians saw was something resembling a kleptocracy. Internationally, this small, secular, oasis of friendly French and English speaking Arabs with a free-market economy became a model of what the Middle East "could be." And, indeed, as many pundits predicted early on, this state would be the first to democratize. What almost no one could have predicted is the degree of Islamist backlash that would result and what its effects across the region would entail. To wit, Tunisia is now the largest single state exporter of Da'ish (ISIS) fighters.

As home to North Africa's single remaining monarchy, understanding the nature of Morocco's regime is key to this work. Morocco, unlike its Maghreb neighbors, achieved independence from the Ottoman Empire in the $19^{\text {th }}$ century. The French colonial project retained and strengthened the Makhzan system between 1912 and 1956. Learning from decades of occupation in neighboring Algeria, resident-general Hubert Lyautey undertook a substantial ethnographic project mapping Morocco's social and political contours to expand the reach of the Makhzan apparatus. Implementation of Lyautey's vision, based on the colonial ethnographic study, imbued the sultan with much greater centralized authority over the entirety of the state. Thus, the dual nature of modern Morocco was created: a modern bureaucracy legitimized with the symbols and rituals of royal prestige. 
North African regimes have been adept at shielding individuals with actual decision-making authority from the reach of their publics' will. The SCAF in Egypt, the Pouvoir in Algeria, and the Makhzan in Morocco all survived the Arab Spring. Egypt's oligarchy remains in power. In Tunisia and Libya, where Ben Ali and Qaddafi maintained relatively narrow power bases, mobilization of regime opposition was made easier. Morocco, in particular, maintains an old and sophisticated regime structure which has adapted over time, making it, perhaps, the most stable and secure of any current regime in North Africa.

Obfuscating the identity, or roles, of actors, to whatever degree possible in a given regime, appears advantageous for three reasons: Domestically, the blame for social woes like a flaccid economy can be placed squarely on the designated head of state, deflecting attention from others who might face public ire. The prime minister of Morocco exemplifies this. He is capable of being replaced, while protecting the regime, should public demand for change require it. Second, it is simply more difficult to rout a regime when there are multiple actors acting in coordination and they remain out of the spotlight such as the Pouvoir of Algeria or the SCAF in Egypt. Third, international attention is directed toward the head of state. It is much better to not have a mark on your head when powerful international agents disapprove of your national policy. Indeed, Qaddafi, embattled as he was by a dearth of trustworthy regime elites, used his country's impressive oil wealth to buy security. In the end, this was not enough to save him from both NATO's imposition of a no-fly zone, and domestic opposition forces based in Benghazi. The takeaway here is not simply that both republics and monarchies use their institutions to deflect blame, but the importance of understanding how their respective 
institutional designs enable obfuscation. How this occurs will be examined in more detail in the analysis section, Chapter 5.

The aftermath of the Arab Spring suggests the outcomes are multi-causal. As Yom \& Gause have argued, the monarchy/republic gap is perhaps only slightly more correlative than a petro-state/non-petro state regime comparison. Algeria is not a monarchy, and yet its regime survived the protests of 2011 without international assistance. Bahrain's al-Khalifa monarchy would have likely fallen had Saudi Arabia not intervened militarily. The "brother-leader" of Libya would likely still be alive without NATO air restrictions. Even without these contentious cases, quantitative analyses have yet to offer "significant" results demonstrating that monarchies are more durable than republics.

The next section examines the various explanations for royal resilience. It reveals the limitations of individual theories to explain the outcome of the Arab Spring and demonstrates the greater utility of synthetic theories, and in particular, the socioinstitutional analysis chosen for this study. 


\section{Chapter 3}

Review of Monarchical Resilience Literature

The chapter locates the strengths and weaknesses of contemporary explanations for the durability of Middle East monarchies and reveals opportunities for theoretical exploration later in the paper's analysis of the Moroccan Arab Spring. It demonstrates the inability of individual theories to explain the Moroccan outcome and the potential for one heretofore unexplored hybrid analysis in application to this state. Using a particular synthetic socio-institutional analysis described in this chapter, this paper contends that the durability of monarchy in Morocco is linked with the Makhzan regime's ability to portray itself as legitimate within the sphere of public discourse by effectively employing its control over wealth and decision-making power. Cooptation of popular ideas and exclusion of opposition voices lowers the need for overt coercion and repression. This system of manufactured consent is what has enabled M6 to survive more than anything else.

As is evident from the previous chapter, the support systems bolstering any regime are manifold. In this overview of analytical frames used to assess the durability of monarchy, the question is: To what degree, and in what ways, might a crown confer advantage over a mere constitution? This section surveys and assesses contemporary explanations of regime durability. These five analytical perspectives are identified in a study on long-term monarchical survival as key approaches to understanding Arab 
monarchies. ${ }^{8}$ They include: institutional, geostrategic, repression, legitimacy, economic and synthetic theories. This section concludes by applying suppositions from this review to the Moroccan case.

But first, prior to covering the contemporary rationales for monarchical resilience, a brief background on two prior discourses is offered: a culturally-based notion of regime resilience and its successor, modernization theory. They serve to demonstrate the theoretical trajectory of responses to this question over the last century.

What explains the high degree of resiliency of the kings? Early theorists focused on cultural explanations. This rationale for Middle East monarchy in the first half of the $20^{\text {th }}$ century located a preference for this regime type in Arab psyche. Both Islam and tribal patriarchy have been targeted as cause for authoritarian resistance in the MENA. These arguments have been omitted from this discussion altogether as patriarchy and Islam are features in both republican regimes and monarchies in the MENA. Morocco's culture, demographics, and ideological development have helped create the existing institutions but antiquated cultural attribution possesses little independent explanatory value. Moreover, these cultural arguments are largely un-falsifiable and, therefore, not properly evaluated through the lens of political science. Cultural explanations, in particular, which draw upon some essential proclivity for monarchy by Arabs are disregarded here. This study omits these rationales for four main reasons: their tendency to essentialize MENA societies; misattribution of general characteristics of human behavior and human society as causes of "exceptional" Arab political realities; lack of

${ }^{8}$ (A. T. Bank 2014) 
explanatory value with respect to the monarchy/republican regime debate; and/or lack of scientific falsifiability.

\section{Modernization Theory}

It is not the form of government but the degree of it Samuel Huntington insisted which is the most important distinction between states. Despite his irreverence for political typology as explanation for the strength of government, Huntington predicted in the 1960s that monarchy has no future in modern society, not because the regime type is incapable of effectively transitioning out of the traditional stage to a higher level of economic development, but because at higher levels of political development, broad social inclusion will be necessary. His king's dilemma noted "the problem is at root one of legitimacy," whereby the king is incapable of simultaneously maintaining support from his traditional base while opening up political space for new social groups. The long term legitimacy of his reforms necessitates broad social inclusion. But the ability to enact reform derives from the king's success in centralizing his power. If the reforms do become successful, the king's traditional legitimacy is undermined as newly included social groups will find the institution of monarchy anachronistic. In other words, "The modernizing monarch is the prisoner of the institution that makes his modernization possible. $" 10$ One would expect from this prediction that the kingdoms of the modern Middle East would be endangered at the very least, if not perhaps near extinction. As of this writing, none of them, in fact, are truly embattled in any serious way, except perhaps Bahrain.

\footnotetext{
${ }^{10}$ (Huntington 2006, 168)
} 


\section{Contemporary explanations}

What follows in the remainder of this chapter is an overview of the institutional, rentier, geostrategic (or external support), legitimacy, repression, and synthetic theories which have been brought to bear on the question of royal resilience. It will be shown that each of these have particular relevance to individual states. But greater explanatory power is found, especially in the Moroccan case, in assessing their efficacy in combination, and why this study utilizes a synthetic approach.

\section{Institutional}

The study and comparison of institutional types has long been a hallmark of political science scholarship. Huntington presaged the imminent demise of monarchies in the 1960s, Subsequent scholarship, particularly from the 1990s, began to rationalize royal resilience as it became apparent that monarchs were not disappearing at the approach of the new millennium.

Institutional arguments are based on the assumption that the structure of monarchies afford them opportunities which republics simply do not possess. Michael Herb's All in the Family explains how linchpin and dynastic monarchies' structure enables political reform. Following the Arab Spring, he presciently notes a key distinction between the Jordanian and Moroccan monarchies from the GCC variety. The linchpin monarchies of the two non-GCC states possess a more singular rule with nonfamily members in charge of various cabinet positions. In contrast, the Gulf States have emplaced family members in virtually all key leadership positions. As Gulf rulers are unable to dismiss or shuffle their family members at will, they are more limited than the 
linchpin monarchs in making rapid administrative changes. This appears to have merit at face value. Both Jordan and Morocco have been noted for their more liberal modernizing monarchs capable of instituting reforms which states such as Saudi Arabia are seemingly unable to enact. Referencing Morocco specifically, Sean Yom responds, "Muhammad VI's real reforms seem more a tactical victory for regime stability than the beginning of real political reform." This is not good news for stakeholders in democracy, but it does reveal a propensity for gradual democratic transition which balances durability with liberalization, and perhaps even democracy at some point.

Following the events of 2011, Herb put forward more nuanced and conditional structural support for the binary regime outcome. He theorized that institutional flexibility and greater credibility enabled monarchs to convince their publics that incremental change was preferable to revolution. Herb posits that a zeitgeist existed across the Arab world whereby poor performance of republican heads gives ideological favor to currently sitting kings. Not so much, he qualifies, that Arabs prefer kings, but that they see these autocratic systems as superior to presidential regimes - at least for the moment.

This argument for a performance advantage is compelling in the case of the GCC states, but lacks rigor in explaining the linchpins. Per capita 2010 annual income in Jordan and Morocco (approximately \$5,000) was lower than both Egypt and Tunisia. Income inequality in these states was relatively the same according to the GINI index (Morocco failed to report.) Victor Menaldo contends monarchies are more accountable than republics. Transparency International's Corruption Perceptions index lends support 
to his thesis. Nevertheless, Tunisia ranked higher than Morocco, but below Jordan. Therefore this relationship remains ambiguous. ${ }^{16}$

What remains most fruitful with respect to understanding the Moroccan regime's durability from this perspective is the potential functional superiority of "rule from above" whereby the Moroccan and Jordanian kings manage to sit above the fray of everyday politics. They are at once more capable than their dynastic counterparts to carry out policy experimentation without pushback from rival family members as they are less directly accountable than republican presidents who must directly absorb public discontent. This is where the institutionalist argument possesses the most explanatory power and thus will be examined at greater length in the analysis section.

\section{Rentierism}

This paper contends that rents play less of a role in the maintenance of power by the Moroccan monarch than in other Middle East states. Lacking the significant petroleum reserves of other regional monarchs like Saudi Arabia and republics like Algeria whose regimes survived the Arab Spring, the Makhzan has survived by using its accumulated wealth and control over decision making institutions to silence opposition and portray itself domestically and internationally as legitimate.

So what is rent in the comparative political sense? A rent is income that requires little or no actual work to acquire. A rentier state is "a government that is able to use its

${ }^{16}$ (Gausse 2013, 13) 
legitimate monopoly over territory to extract significant rents from international transactions and thereby become the dominant actor in the political economy." 17

Operationalizing this definition, a rentier state may be considered as one in which one-third or more of state income is derived from international transactions. Economic rationalization for the continuity of authoritarianism typically centers on the utilization of hydrocarbons as regime-sustaining wealth. Thus, rents have been considered as the "share of state revenues from primary commodities as a share of total state revenues." 18 In this classic account, a regime in power is able to simply convert oil into gold and distribute patronage as the ruler sees fit. In this mirror image of "no taxation without representation," no tax means no representation. Thus derives several corollaries regarding the maintenance of status quo power, including one explanation of gender inequality where petroleum perpetuates patriarchy ${ }^{19}$ Though this explanation for the durability of monarchy has explanatory value elsewhere, it is given less attention in the Moroccan and Jordanian cases where they possess little of the commodity most of the GCC monarchies have in abundance.

The Moroccan elite depend upon tax revenues. Unlike the GCC monarchs which, by state, obtain more than $50 \%$ of their operating revenue from oil sales, the Makhzan relies upon a productive and economically participatory population. This precludes petroleum rentierism as a key mechanism for the perpetuation of power in the Maghreb state at least. Despite being hydrocarbon deficient, M6 has become one of the richest monarchs in the entire Middle East, having acquired several billion dollars of wealth, as

\footnotetext{
17 (Jenkins 2011)

18 (A. T. Bank 2013)

19 (Ross 2008)
} 
the state's single largest corporate stakeholder. Estimates of the value of the king's holdings range from $10 \%$ to $17 \%$ of the state GDP. Therefore a key concern here is, lacking oil revenues, how has he become so rich? Phosphates provide a partial answer here, as Morocco singularly supplies one third or more of the world's demand for this fertilizer base substance. Though not as convertible as oil, phosphates are readily transformed into cash for the Makhzan. The specifics of this will be taken up in the analysis section.

This work takes advantage of a broader conceptual paradigm of rents than mere hydrocarbon abundance in order to grasp the economic bases for economic hegemony in Morocco. Alternative political economy explanations are more expansive and account for incomes derived from both domestic and international sources. Six types of rentierism have been described: natural resource rents, strategic rents (soft loans and foreign grants), political rents including donations to governmental institutions, worker remittances, and international tourism revenues. ${ }^{20}$ Capturing these "indirect rents," as Jenkins et al. do, reveals that international tourism accounted for 10\% of Morocco's GDP in 2008 while remittances made up as much as $8 \%$ of its GDP in the same year. ${ }^{21}$ Overall, combining sources of both direct and indirect rent income, they report that Jordan's GDP is comprised of $49 \%$ of non-taxed revenue while Moroccan GDP is substantially lower at 26\%. Compare this to hydrocarbon abundant Algeria at $72 \%$. These authors found that only Turkey and Israel are less rentierist than Morocco.

\footnotetext{
${ }^{20}$ (Jenkins 2011)

${ }^{21}$ Ibid.
} 
Clement H. Henry's Arab Spring economic thesis states that the pre-colonial histories of state formation in Egypt, Morocco, and Tunisia have given them more robust banking systems that ultimately made these states more hospitable environments for social mobilization. This compliments Anderson's account of regime/state formation during independence. Henry notes that Morocco's “assortment of political parties and civil associations" far outstrips not only Jordan, but the GCC states as well. ${ }^{22}$ Elite control of the banking sector allows the monarchy to give up certain formal control mechanisms while rationalizing the economy. This also happens to give it greater access to international credit. The Moroccan king's great wealth concentration carries financial risks but affords the regime "cushions for political and financial engineering." ${ }^{23}$ This significant economic control could partially explain the monarchy's “institutional flexibility."

\section{External support}

Geostrategic rationale for authoritarian persistence includes foreign diplomatic assurances, economic grants, and military interventions. There is a great deal of empirical support for this proposition as a prop for monarchy in the dynastic Gulf states as well as for the Jordanian monarchy, which shares a border with Israel -- the U.S.'s key ally in the Middle East. The role of external support in maintaining the Alawi monarchy is less obvious, and therefore remains an important point of exploration for this paper. The findings of this analysis contend that external support for the Moroccan regime has less explanatory power than other factors such as the regime's historically derived position of

\footnotetext{
${ }^{22}$ (Henry 2014, 138)

${ }^{23}$ Ibid.
} 
prestige and wealth which it wields to dominate public discourse and silence or even eliminate opposition.

Yom \& Gause maintain that monarchies survived the Arab Spring for three main reasons: First, broad support from cross-cutting coalitions; Second, rents from oil and foreign aid and diplomatic assurances; Third, economic aid and military assistance. ${ }^{24}$ The authors contend, first, that monarchs have been successful due to "historical alliances linking different social constituencies to the ruling family." 25 They argue that greater reward exists for regime supporters who bolster the existing status quo power structure. Revolution is a risky gamble which may cost them everything in the hopes of greater wealth or prestige. While the general public may clamor for the "fall of the regime," dissident actors usually lack the resources and organization to overcome entrenched state authority. In contrast to many Middle East republics, regional monarchies contended with social upheaval early on in the process of modern state formation. Early in their respective post-colonial histories, elite bargains were made which would help the regime to weather future challenges from would be left-wing revolts and military officer coups.

Early post-colonial, post-monarchical republics could have made similar bargains, but instead chose to retain power in narrower channels with resulting regime defects in states such as Libya, Egypt, and Iraq. ${ }^{26}$ Citing Bahrain as a counter-point to the notion that monarchies are exceptional, they demonstrate historically how this modern monarchy remains socially and politically embattled by reliance on eternal actors, such as the British to quash worker riots and Shia protests in the 1950s. The al-Khalifas faced

24 (Yom and Gause 2012)

${ }^{25}$ Ibid., 81

${ }^{26}$ Ibid., 82 
potential overthrow in 2011 had Saudi Arabia not rushed in to save them by sending in a small armada of armored vehicles during the worst riots.

Hydrocarbon rents have been a key suspect in the maintenance of authoritarianism, particularly in the oil-rich monarchies of the Gulf. But as Yom \& Gausse point out, Algeria also possesses rich deposits of gas and oil. These natural resources are easily converted into material inducements which help maintain these regimes' hard-won coalitions. Strategic rents are used particularly in times of embattlement to create jobs, raise salaries, or simply as hand-outs to quell dissent. It was not popular affection for the monarchy in Kuwait or Saudi Arabia that prevented mass demonstrations during the Arab Spring. Rather, it was the ability of their governments to convert black gold into cash quickly. Jordan and Morocco stand out as the two royal exceptions of the Arab world which do not possess such easily convertible natural resources. These authors remark that the promise of $\$ 5$ billion in aid to these two oil-poor states from the Gulf Cooperation Council (GCC) at the height of civil unrest aided their stability by quieting dissent. So, even though lacking in domestic hydrocarbons, their relationship with the Gulf monarchies has given the Hashemite and the Alawi regimes additional protection from social and economic shock.

Finally, foreign pledges of support have strengthened Arab monarchies during potentially regime-ending crises. Saudi Arabia accepted a devil's bargain in taking Israel's greatest ally, the U.S., as its primary benefactor. This has forced the Saudi ruling regime to carefully balance its support for the U.S. military, where it provides military bases, even as public anger at U.S. occupation of Arab countries and Israeli occupation of Palestine remains a critical element of collective Arab outrage. In Morocco, both the U.S. 
and France have provided diplomatic cover as well as economic inducements to secure favorable exchange while treating the monarchy to a share of the spoils.

Military aid in the MENA has two important consequences: it lowers the cost of domestic repression by diminishing international backlash and it arms domestic regimes with greater coercive means. Lack of serious Western criticism of Bahrain's bloody crackdown on dissidents during the Arab Spring exemplifies the first point. Jordan is a key example of the latter, having received over $\$ 12$ billion in assistance over several decades, making it one of the highest per capita recipients of U.S. foreign aid.

Though this sort of international aid can help sustain a regime in the short term, long term regime legitimacy is lowered. The results of arming repressive MENA regimes over the last several decades has caused significant blowback to U.S. and European security: from the overthrow of Mohammed Mossadegh in 1953 leading to the Iranian Revolution of 1979 or the modern incarnation of Da'ish resulting from the 2003 Gulf War. Interventions into MENA states have often been ill-considered and rarely achieved the intended results. (See Chapter 7 for greater depth.)

Yom \& Gause draw two main conclusions from their study: Monarchies remain vulnerable to exogenous political and economic shocks; and second, royals remain in power because of "historical choices and physical resources."

This geostrategic explanation for royal resilience is compelling for several reasons. First, it draws upon the effects of colonialism in Middle Eastern states. In coupling regime choices during state formation to the strength of the monarchical regime, a fuller institutional picture is developed with greater explanatory power than temporal explanations alone. This compliments the insightful work of Lisa Anderson and Mounira 
Charrad, among others, who have described in detail the development of post-colonial MENA states, and the impact this state formation has had on contemporary Middle Eastern society and politics. Second, it is an empirically rich explanation with quantifiable variables. It is easier to detail amounts of foreign aid and to count foreign military air bases than it is to quantify a regime's legitimacy. Third, it is hard to discount the clear connection between rents from hydrocarbons and foreign aid bolstering the ability of autocratic regimes to use coercive means against their populations. Algeria is a hydrocarbon rich state and the only North African republic to have survived the Arab Spring intact.

Despite the strength of the strategic argument for royal resilience, there remains cause for concern with this line of reasoning as an entirely holistic explanation. First, as pointed out elsewhere ${ }^{27}$, the authors reject the role of institutional structure, yet still incorporate a crucial feature, the structure of loyalties. Cross-cutting coalitions incorporate rentierist and legitimacy logics into its explanation, and thus, blur the conceptual boundaries and weaken the distinction between these arguments. Second, the account is ahistorical and fails to account for surveys demonstrating significant levels of support for M6. Understanding the formation and structure of the Makhzan as a patronage distributing mechanism is not accounted for in this externally based rationale for regime resilience.

${ }^{27}$ (Lucas 2014, 200) 


\section{Legitimacy}

Legitimacy is perhaps the most complex concept to understanding monarchical power. It may be defined simply as the ability of government to compel without force. It also refers to popular support for a leader or regime. Precisely which features of the Moroccan monarchy are popular (and why) are less understood. Moreover, discussion of these legitimating features which avoid reductionism and references to a natural predilection for "traditional" Moroccan values has proven difficult. This work explores the micro-mechanisms of norm creation which sustain the narrative of regime legitimacy in the Western Kingdom, and therefore offers a more nuanced understanding of the idea of legitimacy. As will be shown, the ability of the Makhzan to employ its economic and political power to dominate the public discourse has largely bolstered it through periods of challenge.

More formally, legitimacy has been defined as the public's acceptance of rule through mutual understanding and shared values, rather than the imposition of rule through sheer force. Inasmuch as “a regime's procedures for making and enforcing laws are acceptable to its subjects," that regime will require less coercion to enact policy and maintain order. ${ }^{28}$ If legitimacy is largely antithetical to application of force, it is interesting then to consider Max Weber's classic definition of a modern state as a human community that successfully claims the monopoly of the legitimate use of physical force within a given territory. The use of force, Weber asserts, must be legitimated. In other words, it is incumbent upon authority to justify itself and its coercive actions. When public perception deems that a ruling authority has failed to properly justify an action or

28 (McLean and McMillan 2003, 305) 
policy, legitimacy is diminished. Weber offers three bases for such authority: traditional, charismatic, and rational-legal. While these categories have become somewhat dated, they will serve as a useful basis for discussion on proper forms of government. More recent typologies of legitimation have even incorporated ideological and even eudemonic legitimacy, where popular support derives from the leader's trustworthiness. ${ }^{29}$

Believability is, in fact, one of the advantages of kings over presidents according to Michael Herb.

Robert Dahl writes of legitimacy as a function of government effectiveness, whereby beliefs regarding performance are created by political socialization and by perception of performance in the comparison of differing regimes. ${ }^{30} \mathrm{In}$ part, it is regime effectiveness to which he is referring when Michael Herb argues that a zeitgeist exists in favor of Arab monarchs. Scholars operationalize effectiveness in ways which include: economic prosperity, security, political inclusivity, and government's embodiment of collective values.

Monarchical legitimacy, in particular, has a legacy of scholarly attention. Sam Huntington illustrates how modernizing monarchs may draw support from among four sources: the state bureaucracy, the middle class (petite-bourgeoisie), the masses (proletariat), and foreign interests.

Edmund Burke (the $18^{\text {th }}$ century scholar) and Bertrand Russell key in on a psychological component to legitimacy as it pertains to European monarchs. Burke

\footnotetext{
${ }^{29}$ (S. J. King 2009, 13) Here, King references Hesham Al-Awadi in presenting a cognitively-based form of legitimacy. Why a certain leader is trusted or not, however, must certainly derive from his/her past behavior, or at least, that that the current behavior is preferable to "what's behind door number two." ${ }^{30}$ (Dahl 1971, 148)
} 
stresses the power of tradition in developing and supporting national cohesion. Russell perceives a cognitive psychological hold on the mass conscience which derives from propaganda. Marketing regime legitimacy has become more important as the media sphere expands. Capturing the acquiescence of the masses lowers the cost of repression adding substantially to a monarch's cache. ${ }^{31}$

Liberalization in developing MENA states over the last half century demonstrates that these modern regimes tend to assume the institutional trappings of modern democracies, though they typically lack broad commitment to its ideals. Freedom of speech is a norm fundamental to Western liberal democracies. A free press is a primary check on power and therefore something autocratic regimes are prone to curtail and manipulate. Egregious civil liberties violations which could be minimized fifty years ago are nearly impossible to keep secret today. Of course, governments continue to repress, but that the cost of repression is much higher now with social media, cell phones, and global news networks that can more efficiently mobilize international opposition to domestic tyranny. Modern communications more readily allow for the transmittal of legitimizing or de-legitimizing news and images. Control over regime image, therefore, is more important now than ever.

Daadaoui accounts for the symbolic legitimacy of the Moroccan king by use of rituals of power or ROPs. These are historically and culturally resonant symbols and rituals used by the monarchy to exalt its religious supremacy as Commander of the Faithful and as sultan, literally "holder of power," in connoting his authority over government. In his study, he describes the legitimizing impact of these ROPs: the bay'a,

31 (Russell 1938) 
an annual rite of allegiance of the people to king; the Alawite dynasty's sharifian lineage emanating from the Prophet Mohammed which, in turn, endows the king with mystical baraka. Daadaoui's socio-institutional framework to understanding Makhzan power compellingly picks up where rentierist and repression accounts leave off and will be considered at greater length later in this work. Key to this thesis is that these ROPs, perpetuated through a highly controlled media, help to manufacture consent and legitimacy.

\section{Repression}

This thesis contends that M6 has relied on repression far less than his predecessors in the maintenance of his authority, though outright violence against opposition is by no means extinct in Morocco. The use of monetary coercion and access jobs are more frequently used by the regime to obtain acquiescence. Nevertheless, it is the Makhzan's ability to co-opt the public discourse which has kept a critical number of potential opposition actors off the street following the tumult of the Arab Spring.

Morocco's years of lead in the 1960s are synonymous with post-independence power consolidation during Hasan II's reign. Mohammed VI has distanced himself from his father's harsh style of rule semantically and with actual policy. This is best exemplified by the Truth Commission which sought to bring reconciliation for the harsh tactics of his father in the first part of the millennium. This is not to say that coercion does not play a role in subjugating dissent by the current monarch, rather, that systems of coercion to punish regime opposition actors have become less overt, and inasmuch, require a more systematic and nuanced analysis. Hence, the position of this thesis is that 
the façade of democracy requires an ever-more polished veneer in order to maintain its luster and to quell the voices of popular dissent. Is the Moroccan political system truly becoming a constitutional monarchy as M6 claims, or is his regime becoming more adept at applying ever-more covert, yet still effective, pressure on political actors to maintain the status quo? The nature and degree of repression in Morocco shall be examined, particularly with regard to its relationship with legitimacy as these are largely interrelated concepts.

Bellin has often emphasized the role of regime repression in assessing the mechanics of political transition. Her post-Arab Spring analysis has extended and refined her concepts. She surmises that the robustness of authoritarianism in the Middle East is not due to lack of democratic prerequisites, but instead, due to an "exceptionally muscular coercive apparatus" with the capacity and will to thwart democratic initiatives. $^{32}$ This apparatus, she continues, is enabled by rentierism, international supporters, weak institutions, and inability of opposition to mobilize effectively. As with legitimacy, the mechanisms underpinning the coercive apparatus, are multifaceted and conceptually broad. Her analysis of the Moroccan Arab Spring is treated sparingly, left simply with the conclusion that opposition elites had been divided and coopted, while the "protective logic" of monarchy sustained the crown in both Jordan and Morocco. As repression is deemed to be less a factor in the Moroccan (and Jordanian) case, it is left up to scholars of royal resilience to take up the task of contemplating what this "logic" really entails.

32 (Bellin 2012, 128) 
Again, as with our other explanations, we see considerable conflation of repression with other hypotheses; here with rentierism and legitimacy in particular. By definition, if legitimacy is the ability to rule without force, then repression must be its antithesis. Others have noted that Arab monarchs over the last several decades have resorted less often to hard repression than their presidential pretenders while both regime types seem to use soft repression whenever possible. This is clear in the Moroccan case where M6 has actively sought to soften his image by manipulating the media in achieving the desired effect to domestic and international consumers.

\section{Synthetic}

It is through the employment of numerous tactics by which the regime of M6 has survived the Arab Spring revolts. Individual explanations have proven insufficient because they are often mutually interdependent or poorly operationalized. This reduces their utility for understanding what, if any, benefits monarchy has over other regimes with respect to durability. As Lucas notes, no one single explanation can account for the variation in protests during the Arab Spring, but rather, a synthesis of arguments is needed. ${ }^{33}$ His argument for the resilience of the Gulf Arab states during the Arab Spring utilizes three "mechanisms of monarchy": distribution of decision-making power, distribution of economic resources, and distribution of cultural norms. For this reason, this paper utilizes a multi-faceted analytical lens to investigate how the Makhzan has remained in place with its monarch intact.

${ }^{33}$ (Lucas 2014) 
According to Lucas, decision making power among the kingdoms was more widely distributed than in republican regimes. Additionally, elite cohesion was stronger in monarchies than republics which forestalled factional splits like those that led to the overthrow of Qaddafi and Mubarak. Finally, he remarks that military and security services, in the Gulf monarchies at least, were more firmly under the control of the ruling family, thus enabling greater repressive capacity.

In the Arab Gulf, Lucas's analysis of the distribution of economic resources reveals three key features of royal patronage which reinforce collective unity while keeping it fluid and divided: First, citizenship is linked to wealth (vs. non-citizen working class). Second, welfare benefits created a reliance on the state. Third, asabiyya (or social cohesion) in both dynastic and linchpin monarchies, is a mediating feature not present in republics. This institution both rewards patronage and chastens disloyalty. This provides economic resource access as well as social meaning.

During the Arab Spring, the following effects are noted by Lucas: First, regimes "doubled down" on these path-dependent institutions (e.g. stimulus over repression) rather than innovate new tactics. Second, for the regime oppositions, these patterns of allocation influenced their reaction. Socially pluralized opposition groups were less effective at building alliances than opposition in states with polarized cleavages (e.g., Bahrain). In plural societies, regime elites vie against each other for economic resources in a system of competitive clientelism recognizing the supremacy of the status quo. Polarized regime oppositions represent a more serious threat to the status quo, which look to fundamentally alter the balance of power. Rich GCC states were able to offer greater 
economic stimulus packages than Morocco where the regime relied heavily on a pledge to reform the constitution as well as offering economic subsidies.

The third mechanism of monarchy in the Gulf encompasses distributions of norms and identity. Monarchies may be perceived as more legitimate, or authentic, than their republican competitors. Here he refers again to the asabiyya covenant between rulers and ruled. ${ }^{34}$ Public opinion polls show people prefer security and democracy and, in this argument, Lucas reflects Herb's zeitgeist for a popular preference for monarchy. Finally, securitization of sectarian demands, where dissent is linked to terrorism, is a norm that Lucas argues worked against opposition forces in the GCC. This has certainly been a tactic of kings and republics alike. Algeria, for one, has capitalized greatly by depicting its domestic Islamic opposition as a global terrorist threat and accruing significant international rents in its fight against the ongoing GWOT.

He is not alone in the effort to reincorporate culture back into politics. Daadaoui makes the case for the Ritualization of Power in Morocco in his analysis published just prior to the start of the Arab Spring. ${ }^{35}$ In his book, Daadaoui demonstrates how baraka, bay'a, sharifian lineage, and commander of the faithful status has bolstered the monarchy over centuries. How this distribution mechanism of cultural norms sustained the regime through the uprisings of 2011 and beyond needs further attention. The mechanism for this transmission of regime-sustaining norms and beliefs will be assessed in the discussion section of this paper.

\footnotetext{
${ }^{34}$ In this paper, the notion of asabiyya is questioned as it treads dangerously close to explanations depicting a cultural affinity for kings which are eschewed for being irrational.

35 (Daadaoui 2011)
} 
Victor Menaldo makes a case for an "invented political culture" by Middle East monarchies based on a legacy of tribalism which maintains distribution arrangements and sets limits on Arab monarchs. Monarchies are more conducive to the rule of law and have less corruption, he finds, and exhibit greater respect for property rights. This predisposes Arab monarchs to have larger and more robust economies than their republican counterparts. $^{36}$

Precisely how these theories fit into the Moroccan case during the Arab Spring has yet to be analyzed in depth. While a number of scholars have attributed a particular penchant for monarchy to the Moroccan polity, there has been a lack of emphasis on norms, identities, and their manufacture by elites in understanding regime sustenance. Furthermore, the intentional exclusion of linchpin monarchies by Lucas leaves room for exploration on what the NI/SMT synthetic approach might reveal in the Moroccan case.

\section{Suppositions for the Moroccan Case}

"The prevalence of monarchy in the Middle East is best understood as a reflection of the vagaries of historical accident - particularly British imperial policy - and the imperatives of historical process - notably the formation of new states and the building of new nations in the realms until recently ruled by the Ottoman Empire and its neighbors." 37

This section reflects on key suppositions, specific to Morocco, drawn from the literature review. These will be evaluated in the context of the Arab Spring further ahead. Given the primary concern of this paper regarding the interplay between regime and resiliency, the following concerns are addressed in order to provide a historically

\footnotetext{
36 (Menaldo 2012)

${ }^{37}$ (L. Anderson, Legitimacy, Identity, and the Writing of History in Libya 1991)
} 
grounded, holistic account of the Moroccan case: First, how has authoritarianism developed in Morocco? Second, why does Morocco have a monarchy? Third, why has the Alawi regime been resistant to democratic change? Here is demonstrated the complexity of Morocco's regime support, and indications to the utility of a synthetic theoretical approach to its understanding.

Colonial regimes created or enhanced existing authoritarian structures to bolster their state-building projects. Authoritarian regimes were unexceptional in the early $20^{\text {th }}$ century. The proto-state of Morocco was like other colonies with its top-down political structure. As Linda Anderson has written extensively, European colonial regimes followed the British model to control foreign governments in achieving their desired political and economic goals. Anderson notes that monarchies and republics with authoritarian structures were best suited to the task of state building.

Morocco's monarchy existed for centuries prior to direct Western intervention in 1912 when the French colonial regime elected to maintain this form of rule to enhance state legitimacy. Morocco existed largely free of foreign domination following the impositions of the Arab Empire late in the $1^{\text {st }}$ century until the French and Spanish protectorate of 1912. It developed, for a millennia, its own distinct system of patronage, administered by a "theocratic authority supported by traditional oligarchy" 38 in which the regional administrators, both religious and political, held selection authority over the sultan. This power dynamic was strengthened and expanded during the French statebuilding process to provide the colonial regime with direct control over political institutions and the levers of economic control. Today, the Makhzan continues to function

${ }^{38}$ Alain Claisse "Makhzen Traditions and Administrative Channels in (Zartman 1987, 37) 
in this fashion, albeit with different actors and a veneer of electoral democracy. With the departure of the French and Spanish in 1956, the king has usurped even greater power; possessing a monopoly on politics, constitutionally recognized preeminent religious authority, and significant control of the nation's wealth. This may well not always be the case, as the 2011 Arab Awakening has aptly demonstrated the unpredictability of human agency.

Renewing and adapting patronage networks following independence has been critical in maintaining the king's power. This political/economic structure has maintained its resiliency following independence by retooling its networks of patronage interlacing rural, urban, and religious elites; and becoming further enriched by economic allegiance to the West whose wealth channels were dug early in the $20^{\text {th }}$ century to serve European elites first, and the cooperative Makhzan second. The French colonial resident-general's ethnographic and counter-insurgent project envisioned, studied, and superimposed a modern Moroccan state upon the indigenous Makhzan system. It was custom-designed to serve the economic needs of Hubert Lyautey's financiers and maintained the legitimating essence of Moroccan nationhood. Subsequent to Moroccan independence, Mohammed V deftly beat out supporters of parliamentarism by capitalizing on his symbolism as an icon of nationalism, and acquiring new bases of rural and religious support. Hassan II further solidified this base during the years of lead while eliminating or coopting political challengers. Mohammed VI, unable to maintain his legitimacy through brute force as did his father, has used the pretext of liberalization and state-led reform to appease popular aspirations for political inclusion with success at least up to now. 
Based on this review of the literature, this thesis takes a socio-institutional approach to understanding the dynamics of power in Morocco and considers the assertion that the legitimacy of state and regime are mutually interdependent. ${ }^{39}$ It is therefore imperative to first understand how this collusion occurred, and second, to describe how this path dependent trajectory affects Moroccan institutions today. Thus, this section submits that the formation of God, the King, and the Country as pillars of national unity in Morocco result directly from the struggle for power at the finale of the French colonial project. Western intervention has historically been an intervening variable to understanding the success of the Alawi regime during the $20^{\text {th }}$ century and beyond. While it is helpful to consider the roles of Europe and the U.S. in the maintenance and destabilization of MENA regimes during the Arab Spring, the holistic approach applied here seeks to understand the historic and modern role of domestic and international actors on Moroccan regime formation rather than consideration in temporal isolation.

Burke's The Ethnographic State explores the French protectorate's extensive study of the b'led al-siba (land of dissonance). This land mostly comprised Amazigh communities in Morocco's northern Rif and central mountains. The French ethnographic project sought to ascertain the best method of capturing patronage for the Sultan who by 1912 answered directly to the resident-general, Hubert Lyautey. Burke argues that the contemporary monarchy, while importing and embellishing the royal trappings of its regime ancien, owes its existence more to the efforts of the French colonial administration than to its Alawite forbearers who began the dynasty in 1631. His thesis,

39 (L. Anderson, Dynasts and Nationalists: Why Monarchies Survive 2000); (Burke 2014); (Daadaoui 2011) 
avowedly an attempt to define the nature of Moroccan Islam, tends rather to account for the history of the colonial consolidation of power within the Makhzan, at least up until the 1920s.

As noted elsewhere, ${ }^{40}$ he fails to consider that the French protectorate was actually at odds with the sultan as he began to ally with the nationalist movement in the early 1930s. As John Waterbury informs, the republican nationalists had been severely weakened by the French and it was the nationalists themselves who conferred the title of malik (king) upon Muhammed Ben Yussuf whose popularity only increased in exile. It was this moment in history when the monarchy was reinvigorated and King Mohammed V became the symbol of Morocco's past and future. This alliance of traditional and rational authority, or between king and reform, aptly characterizes the regime today. The following chapter discusses how Lucas's NI/SMT analysis will be applied to the case of Morocco's Arab Spring. The methods and types of data collected are assessed to better understand the question of monarchical resilience in North Africa.

40 (Hannoum 2015) 


\section{Chapter 4}

\section{Methodology}

This thesis examines the performance of the Alawi regime in a primarily qualitative study using Lucas's socio-institutional NI/SMT analysis. This section describes this method of analysis in detail, and the types of data collected and examined for this study. This NI/SMT analytical model is used as it affords the greatest unexplored potential utility to understanding the resilience of the Moroccan monarchy as discussed in the literature review. The media content analysis conducted for this study assumes that the decision-making and wealth distributions favor the regime in power. Therefore, this study evaluates the effectiveness of norm distributions in the popular media. The results of this MCA are revealed in the next chapter.

\section{Russell Lucas offers a method of analysis which integrates Social Movement} Theory and New Institutionalism. Indeed, his three mechanisms of monarchism, derived from this synthesis are specific enough to have regime-level analytical utility and broad enough to incorporate the gamut of explanations proposed for monarchical resilience. As part of the normal science process, ${ }^{41}$ evaluation of the Moroccan case through this lens seeks to reveal the utility of this analytical framework to the case of North Africa and linchpin monarchies specifically. Indeed, in reflection on the utility of this mechanism, a brief comparison of this study's findings will be related to the case of Jordan, an

${ }^{41}$ (Kuhn 1996, 29) Kuhn describes this third component of normal science as a “....sort of experiment to articulate a paradigm" and "more than the others, this one can resemble exploration, and is particularly prevalent in those periods and sciences that deal more with the qualitative than with the quantitative aspects of nature's regularity." 
institutionally similar regime type. This paper supposes that the Yom \& Gause "geostrategic" explanation and Herb's regime-oriented rationale of resilience are independently insufficient. A socio-institutional theoretical analysis offers a historically informed, holistic account of regimes and opposition during the Arab Spring. This "pathdependency/political opportunity" dyad does not prematurely constrain the exploration of possibilities; instead, this framework allows for greater freedom of analysis.

\section{Data Collection: Primary and Secondary Sources}

In evaluation of the relative distributions of political power, wealth, and norms in Morocco, this work incorporates a range of sources from Western and Arab perspectives in the fields of history, sociology, and predominantly, political science. Both qualitative and quantitative data are assessed though this study from primary and secondary sources. French, Arabic, and English sources have proven valuable in accessing scholarship, news, media, videos, and blogs from the Maghreb. Independent primary research is limited in this paper, but does include a formal interview with a Moroccan scholar conducted in Arabic and a print media content analysis (MCA). This type of investigation compliments a socio-institutional approach and is appropriate for this topic:

\section{"Media content analysis is a non-intrusive research method that allows examination of a wide range of data over an extensive period to identify popular discourses and their likely meanings. " 42}

This content analysis evaluates 30 newspapers, from February 2013 to October 2013, obtained by the author while on fellowship in Rabat. These were prominently

42 (Macnamara 2005, 6) 
displayed by urban street vendors and cost 3 dirhams - about 30 cents (US). Print media, of this variety, reflects a common source of inexpensive, ubiquitous news in the urban media-scape in metropolitan Morocco. Though an MCA on television may represent a more commonly ingested media form, translation and quantitative measurement of print media proved far more feasible in this case. In reflection of this paper's IT/SMT analytical lens, the MCA measures how the state regime attempts to manage its image while also revealing opposition opportunities for pushback to open up the media-space.

One popular idea put forward in the literature is that the monarch sits above the fray of politics, enabling him to be seen as the peace-maker or arbiter among political factions. ${ }^{43}$ The king is able to deflect blame onto subordinates while projecting an unassailable image. Analysis of Moroccan daily newspapers obtained in Rabat over a period of several months tests this hypothesis by enumerating both positive and negative images and articles relating to the monarchy as well as articles and images critical of regime opposition and prominent figures in government. This quantitative and qualitative analysis gauges the intent of the regime to manipulate public opinion and reveal what these messages contain.

Quantitative analysis of the newspapers involves randomly selecting 30 papers and subsequently enumerating written content and visuals which clearly demonstrated positive or negative perspectives of the monarchy and PJD. Ambiguous articles and visuals are omitted from this study. Articles which were coded as favorable toward the monarchy demonstrably showed the king and his forebears as the legitimate rulers of the state or expressed an intertwining narrative of national history of which the monarchy

${ }^{43}$ (Waterbury 1970, 144) 
was inseparable. Articles with negative views of the PJD typically made specific critiques of the head of government and were usually accompanied with photographs picturing Benkirane as frowning severely, shaking a fist, or looking somehow inexplicably ashamed. Alternately, almost all pictures of the king show him composed, next to other heads of state, and serene.

Qualitative MCA evaluates general themes regarding the royal message and pushback by dissenting voices after review of all newspapers. As the main argument of this paper is that M6 survived the Arab Spring by monopolizing public discourse, I expected to find predominantly pro-monarchy articles and images while coverage of the Islamist Prime Minister Benkirane, and the Party of Justice and Development, will be much more critical. The Moroccan media landscape is closely monitored and controlled by the regime. Those who criticize the crown holder himself are subject to public law and stern economic penalties and even imprisonment. ${ }^{44}$ The content of these public messages reveals the level of dominance the monarchy maintains over print media. Perhaps more interestingly, it shows where the monarchy is most vulnerable to critique.

MCA can decode the regime's intent and measure the effective control it has over the media. What it cannot do, however, is measure the effect of this mechanism on the public sphere. In other words, MCA can reveal the degree of institutionalized manipulation, but it does not demonstrate the degree of absorption of royal propaganda. To measure the effectiveness of this media manipulation, this study relies on multiple sources including survey data and interviews with elites and protestors. This thesis argues the effect of royal media manipulation on Moroccans, has been the critical factor in

44 (Spiegel 2013) Ali Anouzla is one prominent Moroccan journalist who dared critique the king and jailed. 
sustaining the regime's legitimacy during the Arab Spring. Indeed, this legitimacy did not arise overnight, but has been manufactured for decades since independence. 


\section{Chapter 5}

\section{Results}

Discourse analysis from the MCA reveals the Moroccan media projects an overwhelmingly positive image of the king and his forebears. In contrast, Benkirane and the PJD are usually depicted as embattled and politically frustrated. These results align with the institutional hypothesis that the monarchy has both the economic resources and political power to dominate the media sphere in promoting its message (see Table 1).

Table 1: Print Media Content Quantitative Summary

\begin{tabular}{|l|l|}
\hline Pro-Monarchy Pictures & 104 \\
\hline Pro-Monarchy Articles & 44 \\
\hline Anti-Monarchy Pictures & 0 \\
\hline Anti-Monarchy Articles & 2 \\
\hline------------------------- & ---------------------------- \\
\hline Pro-PJD Pictures & 7 \\
\hline Pro-PJD Articles & 4 \\
\hline Anti-PJD Pictures & 33 \\
\hline Anti-PJD Articles & 61 \\
\hline
\end{tabular}

Moreover, the numbers are suggestive of a slightly more nuanced message than absolute media domination by the crown. Deviation from message norms are few, but reveal what may be limitations on institutional media manipulation, or in SMT terms, 
political opportunity structures (POSs). Alternatively, the regime may be intentionally creating opposition media space to give the impression of free speech, much as M6 uses the parliament to give the illusion of an electoral democracy.

Qualitative analysis of this MCA reveals certain themes and trends in the manufacture of consent in Morocco which give insight to interpreting these critical openings, or POSs. There were two overt but interrelated media critiques of the king within this timeframe. The first was coverage of the arrest and detention of journalist Ali Anouzla. He wrote for Al-Masaa' before leaving the paper to take his critiques of the monarchy online in Lakome. Anouzla presented a number of criticisms regarding the royal holdings and was even sued on a few occasions. When lawsuits and fines failed to stop the web site from continuing to expose the immense wealth of the Alawi regime and its corporate allies, an excuse was found to jail him. The journalist was finally arrested late one night in September 2013. Supposedly, according to the charges, he materially supported terrorists by referring to an article with its own link to an ISIS propaganda video.

Not coincidentally, the arrest followed the second media critique captured in this MCA regarding "Daniel-gate.” Anouzla was first to cover the breaking story in 2013 where a convicted serial child rapist, Daniel Galvan, had been pardoned by M6, along with scores of other Spanish criminals, at the behest of Juan Carlos, king of Spain. Though a red line of sorts exists in the Moroccan mass media for criticizing royal wealth, it appears that moral outrages involving the monarchy are harder to censor. This also reveals the influence of European allies and the willingness of M6 to accommodate them. Where the monarchy has the capacity and will to repress journalistic attacks with respect 
to the king's fortunes, it appears less able to use such harsh measures when attacked on moral grounds.

This suggests the degree to which the king relies on his sharifian legitimacy as Commander of the Faithful. Bear in mind, sharaf and honor both possess the same root word in Arabic. His sharifian legacy as descendant of the prophet is a crucial pillar of the king's legitimacy which makes him vulnerable to specific critiques of moral indiscretion or to being permissive of it.

Likewise, despite an obvious disparity in wealth between the king and his subjects, there is nothing in the constitution, or in the rhetoric of the monarchical mouthpiece, precluding him from being unabashedly rich. One could even argue that as a source of baraka (or blessings), the king is also a legitimate source of wealth distribution. This does make sense, to some degree, in tying together the clientelist wealth distribution model of Morocco with his role as distributor of divine blessings. Though speculative, this idea possesses some explanatory power for a particular media phenomenon. One of the most common expressions of thanks in Rabat is Baraka-louw-feek, meaning, blessings be upon you. And as with patrimonial politics, who you know often determines what you can get.

The legacy of the post-independence Alawi royal family is traced and re-traced constantly. In the public media sphere of Morocco, creating and re-creating a public image which connects M6 to his enormously charismatic, though sometimes ruthless, father and to his grandfather, the once living embodiment of post-colonial independence, is of paramount importance. Numerous "historical" articles in these newspapers demonstrate the royal family's venerable legacy and the interconnectedness of the regime 
to state through both description and pictures. This is the hallmark of all nationalism which seeks to tie a particular leader to an ideal or tradition. This is not the province of monarchs alone however as republics work very hard to do the same. For example, the continued reverence for Kemal Ataturk in Turkey is striking. He was a more or less secular-oriented leader re-establishing order after the fall of the Ottoman Empire. Turkish politicians of all stripes continue to present themselves as standard-bearers of his legacy. This is particularly ironic since the AKP, an Islamist party, has been in power there for over a decade.

Turkey's Prime Minister Recep Tayyip Erdogan is given great accord in Moroccan print media. There is even a running featurette on him in one paper. It may be that he symbolizes the right balance of religiosity and secularism, or it may be that the monarchy wants to build a positive image for him domestically to attract Turkish foreign investment. Either way, or both, it is apparent from this MCA that the Makhzan holds special accord for Turkey's leadership.

Erdogan notwithstanding, the Moroccan king is often pictured alongside world leaders: Barack Obama, King Juan Carlos of Spain, and numerous emirates of the GCC are consorts of M6. There is little doubt to the average Moroccan that it is M6 who has the wherewithal to negotiate matters of international significance, not the head of Morocco's government. Benkirane is typically pictured either alone, or bickering with another politician. One article exposes how the prime minister was unaccountably late for a meeting with the French ambassador. Another story shows Benkirane exiting a car after being ticketed for speeding. According to his image in the Makhzan-backed media, Benkirane clearly lacks the gravitas and international acumen of the king. In this vein, 
M6 is not only internationally respected, but domestically, he is the supreme "reformer." The Arabic word for reform "al-salaa" is perhaps the adjective most frequently tied to the king and his visionary projects.

One paper, on the anniversary of M6s rule, has a special magazine attached called "Kingdom of the People." The magazine is nothing less than a magnanimous tribute to the Moroccan monarchy and to M6 specifically. If any one piece of "journalism" encapsulates the complete marketing message of Mohammed VI, it is this one. After recapitulating each and all of his defining sacred and political roles, it closes with a section titled "The People's King" in which he is pictured hunting, playing with his child, and taking a walk with his wife. Though the King and his wife are often pictured in proximity to European kings and queens, historians note that M6s wife is the first Alawi female companion to enjoy the status of spouse, and her official title is not queen. Nevertheless, the invention of a European ideal of monarchy in Morocco is portrayed as if it has always been just as it is today.

Where M6 is shown nearly always in a grand light, almost all projections of Benkirane are either hapless, angry, or at best, placid. When he is portrayed positively in several articles, he is also typically shown giving allegiance to the king in turn. Economic woes in Morocco are consistently attributed to Benkirane as the "head of government." This is most counter-intuitive as he had been in power less than two years. Nevertheless, M6 appears to have no direct influence over the state economy-- if one believes only what is written in the daily newspaper. No shortage of statistics exists, as presented in the media, revealing the high poverty and illiteracy rates in Morocco. The ultimate cause 
however, is never the king, but rather, Benkirane, who is frequently presented as politically impotent, incompetent, and ineffectual.

Morocco's prime minister is often compared (unfavorably) with the deposed Muslim Brotherhood president of Egypt Mohammed Morse. One article in Al'an (Now) magazine asks the question "Is this the end?" with a side by side picture of Morse and Benkirane on its cover. In resurrecting a reverse domino theory of ideological politics, the article presages the downfall of the Arab world's first popularly elected Islamist prime minister.

When not overtly dismissing Benkirane, more subtle techniques are used to present his party negatively. For example, while the name of the party is often spelled out as "Hezb al-adl wa tanmeya" meaning "Party of Justice and Development," it is also referred to as "Bee-Gee-Dee," a direct Arabic transliteration of the English abbreviation "PJD.” In using this uniquely Western abbreviation, a disparaging allusion casts a foreign shadow over the Islamist opposition party-confirmation that a subtle infusion of linguistic and symbolic mechanisms are routinely used in the Moroccan mass media to categorically project an image of Benkirane's party as coopted by the West, when not simply weak.

In one of the most profound political spins, one article contained in a special paper commemorating the second anniversary of Morocco's Feb 20 2011 uprising states that there "will be twice the protest if Benkirane does not fix the economy," according to one demonstrator. This is indeed ironic as Benkirane was not even leader of the majority party until November $29^{\text {th }}, 2011$. M6 is later called the "King of peace" in a time of 
regional turmoil and uncertainty. One headline exclaims that now is the "King's Spring or "Robea al'malik" as prelude to discussing the vision of his planned reforms.

This qualitative analysis has sought to give context and meaning to the quantitative portion of the MCA. While the numbers demonstrate an overwhelming media bias for the king and against the PJD, a more holistic account reveals cracks in the veneer of the king's image as well as opportunities for alternative voices. This is particularly true on issues of morality where the king appears vulnerable to scrutiny and even public censure.

Nevertheless, this media analysis has greater utility in demonstrating the level of control the monarchy possesses over newsprint as well as the particular message it projects. In contrast to the repression and charisma emblematic of Hassan II, his son's reign may be characterized more aptly by its skill at crafting media hegemony. Though violence and economic coercion remain crucial to enforcing the authority of the Makhzan, it is this regime's ability to project an image of reform and stability domestically and internationally, while obfuscating dissonant voices, which explains how M6 maintained power in 2011. 


\title{
Chapter 6
}

\section{Analysis of the Moroccan Arab Spring}

\author{
Introduction
}

Data from the MCA offers evidence in support of the main theoretical mechanisms represented in Chapter 4. This chapter examines who held the most decision-making power during the Arab Spring, how this power was used, and finally how political opportunities structures were created in opposition to existing institutions. Using Lucas's synthetic NI/SMT analytical model here, it will be shown that the Makhzan regime has largely manufactured consent to survive the Arab Spring through its control over wealth channels, control over decision-making authority, and its ability to manipulate cultural norms. This has discredited opposition actors and has given the appearance of legitimacy to a critical mass of the Moroccan citizenry and while also deflecting international censure from powerful Western states concerned with overt repression.

\section{Distribution of decision-making power in Morocco}

If anything defines political power, it is who exactly has input into the policy decisions which affect the social and economic policies of a state, and ultimately who acts as the apex "decider." Though monarchy implies that all decision making authority emanates from an individual, scholars have ironically noted that many current Gulf Arab monarchs currently share decision making power to a greater degree than their republican 
counterparts. ${ }^{45}$ In Morocco, during the Arab Spring in particular, few would question that M6 himself possessed a preponderance of decision-making authority, but to what degree was more of this power distributed and to whom? What effect might this have had on regime stability? This section examines these concerns by assessing the supposed democratization of decision-making during the Arab Spring from both institutional and social perspectives which included a constitutional amendment, empowerment of political opposition, and opening of the social media-scape to dissident voices. From this analysis, I will show that constitutional reforms have been essentially cosmetic, the limited opening given to the Islamist PJD party and contemporaries has proven ineffectual, and dissident voices continue to be stifled. In sum, decision making power continues to reside where it was in the summer of 2013 -- with the Makhzan.

On March 9, 2011, Mohammed VI gave what was undoubtedly the most important speech of his reign in an effort to avoid the same fate as Ben Ali and Mubarak. This speech occurred two weeks after the largest ever public demonstrations since Moroccan independence from France. Between 37,000 and 300,000 protestors took to the streets across 53 cities to demand change much as their Tunisian and Egyptian counterparts had recently done. In Rabat, however, they were not chanting, "al-shab ureed alsqot al-nedtham," the rallying cry of Tunisians demanding the "fall of the regime." Rather, Moroccans held banners seeking a change of government, an end to tyranny, and constitutional reform. Even among the most vociferous opposition, the king was not publicly renounced. He wisely took the opportunity to formulate a substantive

45 (Lucas 2014, 202) 
response promising to implement "authentic democracy and wise governance [based on] the principle of accountability for those in charge." 46

Mohammed VI announced his proposals for constitutional reform three months later on June $18^{\text {th }}$. These included strengthening rule of law and democratic institutions, creation of an independent judiciary, and reforms implementing greater protections for freedom of expression and gender rights. He assured his own powers would be reduced "as much as possible," with the prime minister gaining the authority to make appointments and dissolve parliament. ${ }^{47}$ One notable addition to the new constitution made formal his role as Commander of the Faithful and prompted one Moroccan February $20^{\text {th }}$ protestor to comment, "Before, we had an absolute monarch, now we have an absolute monarch that is a pope as well." 48 The king would, indeed, maintain control over the Ministry of WAQFS and Islamic Affairs, as well as the military and a panoply of security forces, leading one to question whether this was a "real revolution," as one state official exclaimed, or a gambit to incorporate opposition actors and stall for more time as the storm passed.

Lucas asserts that within Middle East monarchies "decision making power was more widely distributed than in republican regimes." He is referring to Gulf monarchies whose family dynasties include many hundreds of family members (thousands in the case of Saudi Arabia.) At face value this seems counter-intuitive. If monarchies are unique in that they feature the narrowest power-sharing band (monarchy can literally be translated as rule of one) then how is it that Middle East monarchies could come to have more

${ }^{46}$ (Benchemsi 2014, 199)

47 (BBC Africa 2011)

${ }^{48}$ Ibid. 
broadly distributed bases of power? If this assertion were to be true, it would seem that the word monarchy is inherently misleading. Drawing upon the examination of North African regime types in the literature review, Libya and Tunisia possessed narrower distributions of elite power that did Egypt, Algeria, and Morocco. In other words, Libya and Tunisia were more "monarchical" in the literal sense of the word than other North African regimes. If the word monarchy is viewed this way, as opposed to whether or not the head of state wears a crown, we might infer than monarchy in North Africa during the Arab Spring was demonstrably less stable than their republican counterparts.

Morocco, as a linchpin monarchy, possesses more singular authority than the Gulf monarchies, but it is more likely that the king's control has less to do with the exact number of people he shares power with than it does the degree of control he has. For historical and institutional reasons, the Moroccan monarchy has been the most stable regime in North Africa in recent times. Moreover, it is clear from this discussion that upon close examination the meaning and nature of the word monarchy is ambiguous. This is particularly true for political scientists who attempt to make precise comparisons among regime types. This present a significant problem for anyone who attempts to make broad generalizations regarding republics and monarchies.

The assertion that monarchy correlates with wider decision making power, as Lucas suggests, fails to account for how the Makhzan, with its locus in the royal palace of Morocco, enabled recent resilience. Both institutionally and cosmetically, Morocco is a monarchy where M6 sits upon a throne and maintains the preponderance of decisionmaking authority. This suggests that concentrated, yet effective, decision-making power, in the case of Morocco proved advantageous. 
The second point Lucas makes on decision making in Middle East kingdoms is, "elite cohesion was stronger in monarchies than republics forestalling factional splits which led to the overthrow of Qaddafi and Mubarak." ${ }^{49}$ Two immediate conjectures come to mind, for different reasons, with each of these "factional splits." The first is that, although the initial protests and conflicts were internally driven grievances, Qaddafi was ultimately ousted due to NATO airpower support. Lucas's focus is on the instances of protests themselves of course, but it must be noted that Qaddafi, one of the least power sharing figures in the world, would likely have remained in place had the major points of state contention not been on or near the coastline with $10 \%$ of the world's "cleanest" oil under theirs sands. If elite cohesion is considered in the re-framed, and more literal, definition of monarchy considered here, where Libya is a "monarchy," elite cohesion was not strong.

With respect to the second conjecture, regarding Egypt, it may be argued that there was no elite rupture. The primary power holders (the SCAF) have remained by permitting and then removing heads of state as they wish. That is not to say there have not been challenges to elite power in Egypt. To the contrary, Egypt has a robust civil society, labor unions, and organizational capacities which placed extreme pressure on the SCAF to respond to their demands. And as with the Moroccan case, promises for reform were made, leaders shuffled about, and changes enacted to the constitution, which all gave the appearance of true reform.

Lucas's third point regarding decision making power in the Gulf is that, "military and security services, in the Gulf monarchies at least, were more firmly under the control

49 (Lucas 2014) 
of the ruling family. Thus enabling greater repressive capacity." This repression encompassed a "securitization of sectarian demands" including force against regimedefined terrorism.

M6 has been adroit in using foreign policy to acquire stature. In the GWOT over the last 15 years, M6 has secured an abundance of military aid from the U.S. During the Arab Spring the state security apparatus was indeed robust and used sparingly, but effectively, when necessary. Nevertheless, repression was not the hallmark of the Moroccan uprisings like it was in Bahrain. The accumulated legitimacy bequeathed to the royal throne, from a range of sources, obviated the necessity for a Syrian, Bahraini, Libyan, or Yemeni style crackdown on protest and dissent. Understanding the nature of this legitimacy is a key concern of this paper. While tens or hundreds of thousands of protestors called for the fall of the government, virtually no one called for the removal of the king. A great deal of the current king's security is due to his father who re-fashioned the military after several coup attempts.

In the Moroccan case, domination of the public discourse during the Arab Spring included: the monarchy promoting itself as the lead reformist, singularly capable of carrying out political reforms while simultaneously using its media control to confuse Moroccans and diffuse the February $20^{\text {th }}$ movement; coopting "Islamist opposition" into "newly opened" political space demonstrating an ability and willingness to keep its promises; and finally, discrediting the coopted former opposition (Benkirane of the PJD) by using the media to obfuscate the actual reasons why the new government is unable to improve the economic situation for the majority of Moroccans. This is, as Russell Lucas calls it, "doubling down" on the regime's old tactics. These tactics have proven 
successful in the past and continue to be so. In one fell swoop, both secular student regime opposition and Islamist opposition were outmaneuvered.

The king learned one important lesson from Ben Ali and Qaddafi during the Arab Spring and, as a result, made key concessions at a critical time when protests came to Rabat. He then used many of the same tactics as his father: media obfuscation, political inclusion, fear mongering to maintain power. There is no guarantee that this formula will work the next time, especially barring real reform by the regime which would ultimately help it to outmatch the "king's dilemma."

\section{Distribution of economic resources in Morocco}

This section will examine the effect of the Moroccan political economy on proregime and opposition actors within the Arab Spring in line with the NI/SMT analytical framework of the paper. The main argument here is that control over massive wealth and its distribution allows the Makhzan, and by proxy M6, to coopt opposition with material incentives and exclude others who cannot be coopted. Rather than using state resources and international monetary aid to repress (i.e. Bahrain, Yemen, and Syria), M6 was able to effectively coopt dissent by use of a mechanism of control that has been several centuries in the development. The Moroccan Makhzan controls a well-entrenched and colonially strengthened economic system derived over a long history of state power consolidation beginning in the $7^{\text {th }}$ century. Explanations which exclude this development are unable to account for economic incentives which bolstered the regime through the massive wave of protests of 2011. Detailed analysis of the Moroccan economy is not 
possible within this work, though it has been done elsewhere. ${ }^{50}$ Instead, an examination of the economic incentives and disincentives during the Moroccan Arab Awakening will reveal how this mechanism of monarchy was used to the advantage of M6 and his coterie of supporters, the Makhzan.

Various political economy arguments, as presented in the literature review, have attempted to explain the range of regime variation during the Arab Spring. The rentierist approach states that control of fossil fuels promotes regime resistance through pay-outs. This may help to explain regime durability in the GCC states and Algeria, but fails to account for regime resilience in Morocco and Jordan. Strategic rents have also been put forward as cause for monarchical resilience in particular, but this too cannot solely account for stability in Morocco. Institutionalists, such as Michael Herb, claim that monarchs can initiate reforms with greater ease than their republican counterparts and that kings promises for reform are more believable.

The first economic argument for regime resilience is rentierism. Oil and gas production in Morocco is paltry; this royal regime is, in fact, a net energy importer. Thus, rentierism has received relatively little attention in the Moroccan case of authoritarian resilience. Hydrocarbons, however, are not the only commodity capable of producing large sums of regime sustaining cash. Morocco possesses as much as two-thirds of the worlds' supply of "white gold," otherwise known as phosphates. ${ }^{51}$ Phosphates are a key ingredient in fertilizers but are also used in lithium-ion batteries, detergents and food additives.

\footnotetext{
${ }^{50}$ (White 2001)

${ }^{51}$ (Pike 2006)
} 
The value of Morocco's phosphate reserves will only rise as the world's population continues to grow and food demand increases precipitously. While phosphate reserves are depleted globally, Morocco continues to expand its mining operations. The king is well positioned to take advantage of this windfall as the "unofficial" owner of the state-owned phosphate monopoly, and largest industrial company, Office Chérifien des Phosphates (OCP)..$^{52}$

According to Bloomberg, through his controllership of the former ONA Group, now known as the National Investment Company (SNI) after their merger, M6 has direct control over all of the state's phosphates as well as Moroccan sugar and steel. In effect, the Moroccan monarchy has a two-pronged economic apparatus for rentierism: it possesses a monopoly over a key commodity and a large share of the manufacturing sector. Manufacturing is what grows economies. Hydrocarbons are renowned for alienating women from the workforce and creating a "resource curse."

In addition to the current mining operations in the mainland of Morocco, commodity exploration of phosphates in Western Sahara and of oil off its coastline may well prove to further enrich M6. This would not only provide additional monetary wealth to coopt opposition and distribute patronage moving forward, but encourages the support of international allies who will increasingly rely on these resources. This certainly helps to explain the U.S. position of tepid support for the Moroccan claim to Western Sahara a position which has castigated Morocco from the African Union and has been a key source of antagonism with Algeria. Suffice it to say, these "indirect rents" are remain an

52 (Bloomberg 2010) 
under-valued pillar of authoritarianism in Morocco. And like Algeria and Libya, this mechanism of control has nothing to do with being a monarch.

The second economic basis for royal resilience states that kings have greater institutional flexibility. This aligns with the discussion regarding the promotion of the PJD to the majority party in the Moroccan parliament. This appears to have some merit at face value in this case study. The cooptation of the PJD during the Arab Spring, as discussed above, was enabled by a system of material incentives which, when operationalized during the Arab Spring, compelled Abdullah Benkirane to assume the role of prime minister as the Istiqlal majority leader within parliament. This served to bolster the prestige of the monarchy by demonstrating its tolerance and inclusivity while enabling it to keep regime threatening dissent outside the media-sphere of political discourse. PJD members, in return, accrued full-time jobs and a level of prestige difficult to obtain in other sectors. ${ }^{53}$

While institutional flexibility has been attributed unique significance to monarchs, the findings here suggest the contrary. Consider, once again, the case of Egypt, whose regime has actually maintained power despite the removal and replacement of two presidents the last half decade. The SCAF, with a hold on the majority of state wealth and the levers of power is able to present a semblance of legitimacy while maintain its hold on power. Algeria's Pouvoir will likely do the same when Boutiflika is replaced. Indeed, the Makhzan's economic stranglehold on the state is far more complete than was the Trabelsi clan's in Tunisia, and its rivals are far less organized and mobilized than in Egypt. Moreover, as will be discussed in the next section, the perception of legitimacy of

53 (Benchesmi 2011) 
the Alawi king is much stronger. The institutional flexibility is, in fact, not a result of some mystical baraka, but the collusion of immense wealth and an apparatus capable of its effective distribution in exchange for patronage.

The third case for economic-enhanced stability during the Arab Spring is an institutionally-framed argument that kings are inherently more credible than presidents. This ties into economic promises for change as well as political. As the MENA region's third wealthiest monarch, the reign of M6 has been characterized by two overarching themes: his status as a reformer and his immense wealth. The latter, of which, is particularly striking since Morocco remains one of the poorest Arab monarchies and the most illiterate. ${ }^{54}$ The disparities between rural and urban with respect to income and education continue to reflect the legacy of the pre-colonial dichotomy bled al-Makhzan and bled al-siba. The rural periphery suffers from chronic economic under-development, under-education, and under-developed infrastructure.

The major challenge the king faces is maintaining his sacred image as Commander of the Faithful and representative of national unity as he assiduously and simultaneously plays the modern role as director of "the king's holdings" - a multibillion dollar enterprise referred to as the National Investment Company (SNI). The vast majority of this company's wealth is held either directly by the king and his immediate family or a small group of close supporters. As the state's sole multi-billionaire, the king sits atop, not only a literal throne, but also approximately $6 \%$ of the national GDP with which is he able to utilize to disperse patronage to domestic clients and lure international business interests.

54 (Hammoud 2005) 
This income represents only one source of monarchical revenue. He derives considerable income from domestic extraction also. As with non-authoritarian regimes, taxes and other forms of government revenue support a panoply of government projects, but in the Moroccan monarchy, a hefty sum goes toward maintaining approximately 15 royal palaces, most of which are care-taken but little used, various palace staff elements, and a series of concentric security forces including the royal gendarme. Naturally, the king and court are provided a healthy salary for their service to the country.

If Mohammed V is to be seen as the founder of the independent modern state of Morocco, and Hassan II seen as the charismatic but stern authoritarian patriarch who was able to consolidate power after independence, then Mohammed VI is bequeathed the role of modernizing reformer. In this role, he has revamped the Moudawanna, a traditional family code which left women far subservient to their husbands and fathers in all legal matters. He promulgated national reconciliation to make amends for the years of lead which characterized the reign of his father. And he has sought to ameliorate one of the oldest social cleavages by making the Amazigh language officially acceptable.

These reformist images have been intentionally crafted and projected through the national media to cultivate legitimacy. Moreover, it is the monarchy's wealth which funds a carefully constructed mechanism of control which seeks to constantly manage the monarch's image in the public sphere. The power of this mechanism is in its horizontal and vertical reach. This mechanism allows the monarchy to promote itself as the unifying symbol of Islam and state while simultaneously holding the greatest share of the national wealth. 
How does wealth translate into credibility? The answer to this question ties together the notion of the king as a descendant of the prophet and control over religious institutions and control over mass-media outlets. The political economy of the Moroccan mass media converts institutional control over decision-making bodies and revenuegenerating bodies into mechanisms for norm-distribution. The monarchy has economically captured the state's traditionally dominant institutions of norm distribution and information sharing: namely, the mosque and the media. Though social media and online organizing has been important for the February $20^{\text {th }}$ movement, scholarship suggests that existing interpersonal networks and the ability to translate these into an effective opposition organization is responsible in countering authority. Hence, it may be argued that, unlike in Tunisia where cross-cutting opposition factions of labor, scholars, and rural periphery united in protest, the opposition in Morocco was more or less limited to disaffected urban workers and unemployed college graduates. Lacking the participation of the mosque, a traditional source of organization in the MENA and labor unions, the February $20^{\text {th }}$ movement was weak from the start.

The monarchical project to control the religious narrative begins with its cooptation of religious institutions beginning in earnest in the $18^{\text {th }}$ century, not long after these autonomous, educational and religious, organizations began to formalize and centralize their own internal operations. The Qarawiyin mosque in Fez, as one North Africa's oldest and most revered universities, was once funded from local families. In the $19^{\text {th }}$ century, as funding registers were rationalized and systems of funding systematized, the palace became more involved with exerting its influence by funding the institution. Naturally, the sultan would insist on being allowed to appoint his own minister to oversee 
this. This centralization of waqf control by the monarch continued across the nation. Eventually, the French protectorate, took advantage of this valuable network by centralizing the authority, ostensibly, under the sultan's authority, but in reality, under the authority of the resident-general. As early as 1915, the Ministry of Habous, which controlled a vast amount of property, now allowed the French, in the name of the sultan, to lease or sell lands as it saw fit. After independence, a once dissident, autonomous network of colleges and religious schools notable for their persistent questioning of the sultan's legitimacy, were now effectively harnessed together and under the whip of the king. 55

Hassan II, early in his reign, used the Ministry of Waqfs and Islamist Affairs to promote his royal sharifian legacy with the production of The Hassanian Lectures. Each Ramadan, the king continues the tradition of convening regime-loyal scholars who present lectures such as "Islamic View of Culture," and "Religion between Moderateness and Innovation, and its Impact on the Moroccan Personality." These lectures are bound together into a book which is then published in several languages. The message in these lectures is quite clear. As Dr. Ibrahim Zeid Kilani notes in his lecture on "The Place of Al-Quds in Islam," he hopes the seminar will:

"... be extended into a national educational and guidance plan to be supervised by [his majesty] and to pull together the Ministry of National Education, the Ministry of Waqfs, the Ministry of Information, the universities, and the national press that they can carry out the plan of developing an Arabic Islamic identity..." 56

\footnotetext{
55 (Cizakca 2000)

${ }^{56}$ (Kilani 1986)
} 
A cursory reading of the lectures reveals this Arabic Islamic identity is one where the king maintains absolute political and religious institutional control in mediating the inherent factionalism of a pluralistic country. In sum, M6 possesses economic control over all of Morocco's mosques and the messages they disseminate. This degree of religious control is unprecedented in the MENA region and a powerful mechanism in controlling the media-scape.

Control over the press is a second component of monarchical hegemony over the media-scape which has enabled its survival during the Arab Spring. First, the state owns and directly operates numerous television and print media outlets. Second, independently owned publishers and broadcasters are subject to severe monetary penalties for critiques which are more or less arbitrarily defined by the Makhzan. Third, when self-censorship and economic penalties fail to dissuade writers from overt attacks on the regime, arrest and detention is the last resort in maintaining the status-quo.

Ahmed Benchesmi has been an outspoken regime critique prior to, and throughout the Arab Spring. His depiction of the Moroccan media-scape is illuminating. ${ }^{57}$ The assumption of the throne by M6, following the death of his father in 1999, ushered in a period of media openness previously unseen. This "nouvelle presse" was permitted by the regime as it echoed the message of reconciliation and reform with which the king sought to brand himself.

This period of press freedom was short-lived. Young, foreign-educated Moroccans returned home, inspired to promote real reform, eventually turned their attention from the previous king to the present one. Simultaneously, the regime began

57 (Benchesmi 2011) 
facing pressure from several domestic terror attacks: Casablanca in 2003, Casablanca again in 2007, and Marrakesh in 2011. These attacks gave the king popular support, (as it did in the U.S. and in Europe) to restrict personal freedom in its fight against regime outlaws while garnering international aid and diplomatic assurances for its assistance in the Global War on Terror.

Lawsuits and fines were used to put publications out of business. According to Benchesmi, his ability to connect with the international media allowed him to bring global attention to the regime's injustices. This, in turn, prompted the regime to temper its clampdown. A cycle was created; restrictions by the palace would result in increasingly scathing critiques by the "nouvelle presse," which were used to capture global headlines. This escalation of repression and press attacks resulted in imprisonment for various journalists, including Benchesmi. He points out that the Moroccan media has been unique in giving the impression of openness to the world community, while domestically, the media-scape is carefully manufactured and regulated by the makhzan coercive apparatus. Moreover, advertisers in regime critical publications are financially compelled by pro-regime big business to take their advertising dollars to more regime friendly journals. This mechanism of censorship is not unlike that in free-enterprise Western nations.

The result of these tactics is a conditioning of Moroccan media outlets to promote a regime approved message. This aligns with the findings of the MCA in this work. The synthesis of a controlled domestic media with a regime dominated religious system effectively creates hegemony over the Moroccan public discourse. Furthermore, in giving the perception of a "free media" to international news sources, M6 effectively touts his 
international prestige; leading numerous Western leaders to hold up the "Moroccan example" in contrast to the despotism and repression found in other Arab regimes since the Arab Spring. Indeed, Benchesmi reveals his own conflicted thoughts on the matter, reflecting on how effective this system is at manufacturing consent, in contrast to journalists in neighbor states who are subject to more grievous forms of repression. ${ }^{58}$

Lucas states that during Arab Spring, regimes "doubled down" on path-dependent institutions (e.g. stimulus over repression) rather than innovate new tactics. Rich GCC states were able to offer more economic stimulus packages while Morocco resorted more on pledges to change the constitution. Hence, unlike Ben Ali and Mubarak who failed to quickly take control of the popular reformist discourse, M6 publicly pronounced the beginning of a new era in 2011 starting with a constitutional monarchy.

On March 9, 2011, M6 gave, as it was proclaimed at the time, a "historic" nationally televised speech. In it, he spoke at length of "regionalizing" the Moroccan political system. This was essentially saying that he intended to give more decisionmaking power to all. While he spoke of rationalization of democratic institutions, there was almost nothing said about the huge wealth disparity and finding ways to redistribute this massive inequality. He did announce that, "representation of trade unions and professional organizations... remains guaranteed" by the Economic and Social Council, but he failed to explain how this might improve the economic situation for the one fifth or more of Moroccan who were impoverished. ${ }^{59}$

\footnotetext{
${ }^{58}$ Ibid.

${ }^{59}$ (BBC Africa 2011)
} 
One wonders how such a monumental speech could be made without addressing the preeminent cause for concern for the majority of Arabs - economic privation. Passing the buck on the disastrous wealth inequity of the Moroccan economy is sine qua non for the leader of the Makhzan. As the primary recipient of royal patronage, the Makhzan has no desire to draw attention to the supreme level of wealth the king maintains and distributes. In the king's speech, the assumption could be drawn that the government (led by the prime minister) is in charge of the economy and that by strengthening democracy, this would lead to more widely acceptable economic outcomes.

Lucas also informs that for the regime opposition, patterns of allocation influenced their reaction. Socially pluralized opposition groups (such as Morocco) were less able to build alliances than in opposition in states where polarized cleavages exist (like Bahrain). In the Moroccan case, the PJD has been groomed for the last decade as a domesticated Islamist "opposition" which could be used to accentuate the role of the monarchy as arbiter over political factions. And it has, indeed, been the Makhzan system and its system of rewards which has lured young Moroccan Islamists into the political arena, despite the party's historic alliance with outlaw Islamist hardliners like Justice and Charity. ${ }^{60}$ According to Avi Spiegel, members of the PJD, unlike Justice and Charity, have allowed their religious message to be "watered down" even calling themselves a party of "Islamist reference" rather than Islamist -- at the King's behest. While Justice and Charity boycotted the historic election which brought the Arab world its first Islamist prime minister, Benkirane was honored by the King personally as he took his new position. Why did the PJD do this? Spiegel responds:

60 (Spiegel 2013) 
"Party activists wanted to continue to reap the spoils of electoral inclusion: the jobs, the generous state electoral funding, the fancy party conventions, even the respect that comes with wearing suits and campaigning for office. During my two years of field research among young Islamists in Morocco, PJD activists would often tell me: "We are here because we have a future in the party." In a country of mass unemployment, where young people's futures are far from certain, this was a powerful inducement. " 61

Urban elites have the education, connections, and access to the Makhzan spoils system. The last two decades, however, have brought a massive migration of rural youth to cities seeking work and opportunities as the regime implements neo-liberal reforms. This modernization of the economy, in reflection of the King's Dilemma, is straining the monarch's modernization efforts.

In sum, the Moroccan Makhzan has adroitly used its immense control over the state economy to ensure its survival during the Arab Spring. As has been shown, indirect rentierism remains an often under-analyzed facet of this regime's resilience. Its economic dominance is bolstered by the king's holdings which enables international investment to accentuate his portfolio while leveraging international support. A legacy of economic and institutional control over the state's religious institutions has prevented a key opponent of many Arab regimes from mounting an organized assault on the regime or even tacitly joining forces with secular opposition to push for regime change. Finally, the media in Morocco has been silenced, co-opted, and quelled through lawsuits, fines and even force.

This economic control is vital to understanding the monarchy's survival, but it is not sufficient. The regime's durability emanates from the codification of the king's

${ }^{61}$ Ibid. 
inviolable sanctity. How this massive wealth patronage system creates a culture of monarchial affinity is discussed in the next section.

\title{
Distribution of norms in Morocco
}

\begin{abstract}
"By invoking culturally and historically resonant symbols, the regime reproduces legitimacy. However, these symbols are not independent as the monarchy helps shape the way they are perceived in society. In other words, the monarchy does not piggyback on the resonance of the symbols; rather, it manufactures symbols that become subsequently important in society because they are tied and used by the regime. This contention sustains the argument in the literature that political authority lies with those that control dominant narratives, in addition to dominant political and economic structures. $" 62$
\end{abstract}

One of the most notable distinctions of the Moroccan Arab Spring is that virtually no one called for the removal of the king within Morocco. Explaining this result is key to understanding the legitimacy of this regime. It not only reveals the depth and extent of regime control across political and economic sectors, but demonstrates how the monarchy uses its power to construct and disseminate a narrative which bolsters its image and enables scholars to understand how the king's promises for reform were made believable. The previous sections demonstrated how the regime uses its political and economic institutions to gain hegemony over the public discourse for reform. The question asked here is: how effective has the regime been at imparting its message? This section examines regime legitimacy by assessing public perceptions of the regime. This is largely accomplished through surveys to determine what regime features appeal to the Moroccan public. Survey data, obtained largely through secondary sources, interprets the various

${ }^{62}$ (Daadaoui 2011, 74) 
types of legitimacy discussed in the literature review, revealing popular opinions of governmental performance, institutional trust, and state rituals of power (ROPs). Much of this data draws upon an independent survey headed by Mohamed Daadaoui encompassing a broad demographic sample of 287 respondents in the greater Marrakesh region from December 2006 to January $2007 .{ }^{63}$ Other sources of survey data for this section are cited specifically.

The first question in assessing regime legitimacy is, what do Moroccans think about their government's performance? The results are lackluster: $87 \%$ viewed the government's fight against poverty as very bad or bad. Even though the king declared himself, "king of the poor" in a national campaign to overcome poverty, material circumstances were not enough to compel residents in and around Marrakesh to think this was a winning battle. Moreover, $80 \%$ of respondents view corruption as bad to very bad. Other indexes on government performance are much the same: jobs, prices, income, education, and health, across the board are given dire ratings. At least in and around this one Moroccan city, perceptions of government effectiveness are poor.

How do Moroccans assess their state institutions? Daadaoui hypothesizes, given that perceptions of government performance are so poor, Moroccans' views on government institutions, including the monarchy, would be reflective. His findings show that, in fact, yes, perceptions of government institutions are low - except for one. While the king enjoys the trust of approximately $65 \%$ of his subjects, $71 \%$ of respondents distrust their local authorities. Moroccans largely see the monarchy as separate from the government with $27 \%$ expressing very low trust in the king. Findings from this paper's

${ }^{63}$ (Daadaoui 2011, 89) 
MCA align with the survey's results. Popular media is extremely critical of Benkirane, the PJD, and other government officials, as table 1 shows, whereas the king received sparse negative commentary. As previously discussed, there is a high degree of journalistic self-censorship in the Moroccan media-scape given the consequences for public dissent. Still, in a survey such as this one, where respondents have anonymity, a $65 \%$ popularity rate for a state leader is extremely high relative to any of the world's regimes. Clearly, socioeconomic performance cannot account for the popularity of the monarch. Daadaoui, for one, locates the source of the king's power elsewhere - in the regime's manufactured rituals of power. ${ }^{64}$

This final mechanism of monarchy depicts a normative approach by which the Alawi regime manipulates public opinion in the maintenance of authority. In essence, the Makhzan capitalized on a historically and culturally imbued mechanism that Daadaoui terms "Rituals of Power," or ROPs. As he explains, "the popularity of the king is the result of years of increased ritualization of the political discourse performed by the regime around specific sociocultural sources of legitimacy" and that this has outmatched its competitors, including: "political Islam, military coups, socioeconomic imperatives of modernization, and deteriorating economic conditions." 65

How do Moroccans view state Rituals of Power? The results of Daadaoui's research are evocative. Here, Daadaoui queries public perceptions of baraka, amir almu'minin, bay'a, and sharaf. His findings bolster the hypothesis that the king derives significant legitimacy from both traditional and religious symbols. $74 \%$ of his

64 (Daadaoui 2011, 91)

65 Ibid. 
respondents believe "the king as the commander of the faithful to be a religious symbol... and a traditional symbol." 66 72\% and 77\% viewed baraka and the king's prophetic lineage as religious and traditional respectively. The bay'a, interestingly, showed $56 \%$ of respondents viewing it as a religious and traditional symbol of authority, while over $30 \%$ saw it as a contractual covenant between the people and the king. Daadaoui notes, in a bivariate analysis, that illiterate Moroccans are significantly more likely to view the bay'a as a source of religious legitimacy than as a covenant. This aligns with the assertion that traditional/religious legitimacy has long bolstered the monarchy in the bled al-siba (land of dissonance) where the economic benefits of Makhzan patronage have been less inclusive.

Daadaoui's analysis finds that "the link between lagging economic performance and legitimacy is not sufficiently established empirically in the literature on monarchical authoritarian survival. ${ }^{\prime 67}$ Comparing this with the earlier discussion of decision-making power and wealth distribution is useful. Moroccans clearly face a dearth of decisionmaking power. To engage at all in the political sphere means doing so as a dissident (i.e., Justice and Charity). This entails both ostracization from public decision-making bodies as well as official bodies receiving government funds - which are many.

Despite these extremely poor views of governance, Moroccans refused to call for the fall of the king when the opportunity to do so came on February $20^{\text {th }} 2011$. Given Daadaoui's compelling research, one is left wondering whether popular belief in the

${ }^{66}$ Ibid.

${ }^{67}$ (Daadaoui 2011, 94) 
sanctity of the king sufficient to explain why protests were unable to achieve real material change in the distributions of wealth and power.

One provocative response to Daadaoui's legitimacy argument emanates from an essay by Chris Hedges on the isolation of politically disenfranchised classes. ${ }^{68}$ Those excluded from the political power game become emotionally frustrated and seek amelioration outside existing structures. Sociologist Emile Durkheim's notion of “anomie," recounts Hedges, whereby individuals become "easy prey to propaganda and emotionally driven mass movements." This also resonates with Huntington's King's Dilemma logic that modernizing monarchs must struggle with maintaining their traditional bases of support while incorporating new ones.

Hedges' article depicts this social alienation as primer for regime toppling backlash. But Durkheim's anomie also describes "a condition in which society provides little moral guidance to individuals..."69 as a component to this blowback. And in most Arab states it has been the mosque has given this moral guidance and which has absorbed and channeled mass social frustration over several decades. It is this capacity of the mosque which has made it such a threat to modern Arab regimes - regimes which have lost their fundamental legitimacies through duplicity and corruption.

In the case of Morocco, individuals are clearly disenfranchised from the political game. But the Moroccan Makhzan has successfully coopted the religious narrative and virtually eliminated it as a threat - as Daadaoui narrates. What Durkheim's "anomie" adds to this is subtle but important. It is not so much that Moroccans are naturally

68 (Hedges 2016)

${ }^{69}$ Ibid. 
conditioned over centuries to believe in the sanctity of the king, but something far more temporal. In effect, Moroccans have been economically, politically, and even normatively constrained by a holistically hegemonic regime in consolidation of its power since independence. Where Durkheim's account allows for the growth of uncontrolled social frustration through lack of "moral guidance," the Ministry of Waqfs gives Moroccans the proper "guidance" in order to avoid unwanted reprisals. In short, it is not sufficient to say that Moroccans "accept" the will of the king, but instead, at the moment, they simply believe they have no other alternative. And given the political outcomes following various mass mobilizations of Arab populations in the last century, this is not an irrational thought.

Anomie, per Durkheim, arises from a normally quiescent population. Think of Tunisia in November of 2010 when virtually no one believed a new Arab Uprising could be only a month away, much less be initiated by a largely subdued segment of its unnoticed periphery. To dismiss the potential for potentially rapid social mobilization in the Moroccan Rif or elsewhere is to repeat the same patterns of thought leading up to the Arab Spring. Undoubtedly, M6 is well aware of these dangers, and hence why he so hastily initiated concessions and appeasements in February 2011. Despite the hegemonic control described in this paper, political scientists have been humbled time and time again as to the timing of political upheaval. The Moroccan case should be seen in this light. It is a regime which has effectively coopted and dominated its elite opposition and given its masses little reason to believe removal of the king would result in preferable economic outcomes. And, for now, low levels of human development are the key drivers of Moroccan discontent. As long as the monarchy keeps the blame for the state's economic 
woes squarely on the shoulders of the PJD in the public media-sphere, it stands a good chance at staying resiliently in charge.

Michael Herb claims that a zeitgeist for monarchical preference across the Middle East was, at least in part, due to innate institutional flexibility. He cites Morocco as the prime example of a state with large protests who were quick to dissipate once the king signaled his intent to reform the constitution. Despite a large number of regime skeptics, Herb writes, “...the king did not need to convince all of his opponents of the authenticity of his reforms; instead he needed to mobilize his supporters and prevent opponents from gaining control of the terms of the debate."70 Daadaoui's survey gives credence to a popular preference for maintenance of monarchy, which aligns with Herb's point. It will suffice here to say that there was a demonstrable preference by a large enough segment of Moroccans in early 2011 who supported maintaining the king even as they were emboldened to ask for a more rational constitution and greater personal freedom.

Lucas supports his thesis that monarchs are institutionally unique by operationalizing asabiyya: a key feature of royal patronage which reinforces collective unity, while keeping it fluid and divided. It rewards patronage, chastens disloyalty, provides access to resources and even social meaning. Asabiyya is a social construct which derives from the $14^{\text {th }}$ century North African scholar and polymath, Ibn Khaldoun. This concept of social cohesion, uniting people, is not unlike the idea of nation as posited by Benedict Anderson. Where the Gulf monarchies use their petroleum wealth to obtain popular acquiescence, the linchpin monarchies have relied more heavily on narrative creation, tying their leaders to a legacy of sharifian prestige. This is a difficult concept to

70 (Herb, Institutions and zeitgeist: regime type and the pattern of protests in the Arab Spring 2013, 21) 
operationalize. Furthermore, it is even more difficult to separate asabiyya in monarchical regimes from asabiyya in republics. Cultural norms and rules are constituent parts of regimes but it remains unclear how this would explain the durability of monarchies.

Khaldoun, a renowned Tunis-born sociologist, offered another theory; namely, that empires often remain in power for just three generations. As the lineage progresses from warrior-nationalists to sedentary sybarites, the monarch's coterie of regime elites become inured to a life of wealth and luxury. The king is forced to outsource his defense and administration, as his closest supporters begin to lose the respect of the citizenry at large and the fear of his rivals. If one is willing to concede that the post-independence Alawi regime is a singular empire joined by a sense of asabiyya, with Mohammed VI as the third in line of the succession, one is left to wonder about the ancient wisdom of a $14^{\text {th }}$ century scholar with regards to its finale.

In sum, there is compelling reason to believe that a significant number of Moroccans see the king as a legitimate actor. Given they did not call for his removal on February $20^{\text {th }} 2011$, and trusted him to conduct reforms of his own accord thereafter, reveals a certain level of trust in the royal institution. This has been largely enabled by control over his public image through the media and the mosque. Casting himself as both the sacred and rightful heir of a prophetic lineage and the state's lead reformer is the third component of the Makhzan's system of manufactured consent. Support for M6 is not universal however and is contingent upon his continued ability to sustain his own popularity. 
A synthetic analysis of Moroccan monarchy

"At the moment we are seeing an epochal transition. The current conflicts are no longer simply over tactics or various strategies of modernization. There is now a struggle for control of the very concepts of political life, for control of the way people think about politics, and the way that we can talk about polity and society. What we are seeing now in this crisis of authoritarianism is the battle for hegemony over discourse. If you can control the words, you can control the polity."

-John O. Voll ${ }^{71}$

It is clear from this analysis that an interdependent relationship developed between Western intervention and state legitimacy in Morocco due to a harnessing of the traditional Makhzan by the colonial regime during the state building process, and that Western economic and security interests continue to bolster the post-colonial Makhzan's dependency on European wealth channels and the king's dependency on U.S security assistance. Nevertheless, if the Arab Spring has shown anything, it is that human agency is just as important as institutional frameworks and historical determinism.

In the last century, numerous MENA kingdoms fell: Tunisia, Egypt, Libya, Iraq, Afghanistan, Yemen and the Ottoman Empire. It is neither pre-ordained that monarchy will continue indefinitely nor arise in the first place. The question this thesis asks is what enabled the regime of Morocco to make it through the Arab Spring? In the first place, it is more likely that a system in power, at any given moment, will remain in power than it is to fall. An object in motion will continue on its trajectory until acted upon by an outside force. This "Second Law of Power Dynamics" compels us to believe that any force

${ }^{71}($ Voll 1997, 15) 
required to remove and replace a power system must be a significant one indeed. For various reasons, as discussed, no oppositional force was powerful enough in Morocco to displace the current Makhzan. When the regime is threatened, the Makhzan is able to effectively deploy propaganda, resonating with "traditional" values, and dominate the media-scape. During the Arab Spring, this propaganda capitalized on the cultural symbols and religious beliefs of Moroccan society and a manufactured history of monarchical legitimacy.

The relevance of this thesis to the republican-monarchy debate is that psychological factors, less well assessed in political science literature, are the dark matter of this field: less well understood but hugely impactful. The relative performance by monarchies and republics of late notwithstanding, statistical significance is lacking in studies which claim to show that regime type alone is a key factor. Better understanding the mechanisms of psychological power which create both fear of destabilization of the status quo, and through which narrative creation and symbolism create legitimacy will give greater insight into regime durability.

While state legitimacy and monarchy are currently bound together in Morocco, it need not always be so. Lisa Anderson has aptly documented the peculiar nature of Middle East state formation and its relationship to monarchy, but history shows that the marriage of monarchy and state legitimacy may not last. The Ottoman Empire ruled most of the Arab world in sultanic fashion, yet at its demise, was replaced at its core by a secular regime which seemingly engendered as much nationalistic reverence as did the Muslim caliphate. This comparison bears further comparative fruit in that while Ataturk was a secular nationalist, the current regime in Turkey is quite the opposite, and still, this 
founding father remains the mascot of secularists and religious conservatives alike who seek to bolster their faction's legitimacy with his image by reinterpreting his words as befits their political aims.

It is just this sort of fluidity of perception which demonstrates the utility of creating and controlling a popular narrative and attributing it as actual historical fact. The Moroccan monarchy is doing just this - controlling the narrative by controlling not only public spaces, but by controlling public discourse. It is this manufacturing of consent typified by promulgation of a largely symbolic narrative to a hugely impoverished and illiterate nation which has enabled the Makhzan to survive, which is unique to the Moroccan case, alongside its dominance of political and economic spaces.

Though it has been argued elsewhere that monarchy may confer an institutional advantage over republics in the Arab world, it is more likely than not that, ultimately, this advantage is not attributable to a domestic predilection for a sacred leader or to some tribal or traditional sociological aspect, but rather, their existence has been enabled by the historical fact that virtually all the political regimes of modern Middle East states were created by competing Western states vying for their control in the early $20^{\text {th }}$ century. The systems of control which were fabricated at their birth continue to influence their respective domestic balances of power today whatever the regime type. It just so happens that France worked very hard to instantiate the Moroccan monarchy with great economic, political, and symbolic power during its colonial stewardship, (it chose to do the opposite in Syria). The West continues to derive economic advantage over these relationships, hence, why "international stability" continues to be a key foreign policy objective of certain Western powers. It did not necessarily have to be that way and it almost certainly 
will not remain in such a fashion indefinitely. The Arab Spring has, once again, demonstrated the power of human agency in reshaping an institutional legacy when the time is right. As Hicham Alaoui, academic at Princeton, self-exiled Moroccan prince, and cousin to M6 has stated, the Arab Spring is a process... Not an outcome. ${ }^{72}$

An integrated thesis

Despite a profound democratic zeitgeist in 2011, the king survived by utilizing all the tools available in his royal kit: promises for economic reform and greater employment, assurances to the public for greater political inclusion, a constitutional amendments, acceptance of assurances for international aid and support, division and cooptation of the opposition, and manipulation of the parliament. But what is most prominent was the ability of the king to manipulate public opinion by drawing on his legitimacy reserves which reduced the potential costs of using repression.

Mohammed VI's legitimacy is demonstrably real, yet is predicated on deep channels of wealth derived from economic reliance on Europe, security ties to the US, and a highly entrenched Makhzan. Throughout the Arab Spring, these mechanisms of power were used to manufacture consent by obfuscating the message of the opposition and presenting the king, himself, as the lead reform figure. The resulting monopoly over public discourse in the media and in public spaces enabled the king to maintain his throne. This retention of power was not due only to a few smart choices, but rather to a few critical decisions bolstered by a historical legacy of culturally-resonant

72 (AlamiI 2014) 
institutionalized propaganda, economic coercion, colonial manipulation, and overt state violence.

This regime has yet to be significantly disrupted by popular mobilization. During the Arab Spring, the king's legitimacy rested on popular expectations for reform. The Arab Spring is, in essence, a popular outcry against incredible wealth disparity, unemployment, and government corruption. This was more a "democratic zeitgeist," by Moroccans which was effectively co-opted, suppressed and diffused by the king, than a statement on preference for a particular political regime type. 


\section{Chapter 7}

Impact of Mechanisms on Jordan

Given the findings from this analysis, might we expect similar rationale for the MENA's other linchpin monarchy's survival during the Arab Spring? This section will compare the lessons learned from Morocco in a geographically disparate, yet institutionally similar regime. The objective here is not to provide a comprehensive analysis of Jordan's Arab Spring. Instead, lessons derived from the foregoing study are used in an abbreviated comparative sketch intended to provoke thought for future analysis. This brief comparative analysis suggests it is not so much that monarchy matters, but that the concentration of power and the skill of the regime at wielding it matter more. Powerful states, like the U.S., remain powerful intervening variables both theoretically and literally.

Jordan gained independence from Great Britain in 1957; one year after France released its colonial grasp on Morocco. Like the Alawi dynasty, the Hashemites of Jordan also lay claim to a sharifian lineage. Jordan's current ruler, Abdallah II, was enthroned the same year as Mohammed VI. The superficial similarities are remarkable, but state formation in Jordan was a much different affair than in the Western Kingdom.

Unlike Morocco, which entirely avoided Ottoman control, the region which would one day become Jordan came under the authority of this vast empire in the early 1500s. Though the current state of Jordan contains a wealth of archaeological wonders largely in the south in the ancient city of Petra, Jordan lacked a modern urban center until 1921. Britain found Amman to be a useful entrepot in the march toward Damascus during 
the Great War. The British found support from Sharif Hussein of Mecca in the Arab revolt against the Ottomans in World War I. In return for his support, the greatgrandfather of Abdullah II was promised a grand Arab empire of his own, but he would soon discover that assurance to be somewhat lacking.

The takeaway from this admittedly brief historical account is that Jordan possesses a fundamentally different legacy of state formation than one finds in Morocco. The latter monarchy has maintained an element of unadulterated stateness for several centuries, versus the Hashemite kingdom - which resembles a recent cobbling together of tribal elements under the supervision and guidance of an entirely Western-made and funded monarch. What is most striking in this brief comparative analysis is how these two supposedly "similar" states are now considered as such despite disparate geographies, demographics, economic systems, and ultimately.... popular perceptions of legitimacy.

Distribution of decision-making authority in contemporary Jordan owes as much to its emulation, though as façade, of Western electoral institutions as it owes to its mimicry of an antiquated, and arguable more relatively fragile, ${ }^{73}$ institution of Western monarchy. Jordan, like Morocco, initiated a system of electoral authoritarianism ${ }^{74}$ shortly after independence from its mandate overseer. Both monarchs draw the majority of their support from the periphery: tribal leaders, or sheiks, in the case of Jordan and caids or pashas in Morocco. Nevertheless, even with a variegated parliamentary, neither Jordan,

73 (Lucas 2014, 197) Despite having approximately 1/5 the population of Morocco, the Hashemite Kingdom saw perhaps twice the number of protests during the Arab Spring - Bahrain was the only MENA monarchy to have more. Nevertheless, protestors in Jordan only called for expansion of political freedoms rather than removal of their king.

${ }^{74}$ (Schedler 2006) 
nor the Gulf GCC member states, possess the "assortment of political parties and civil society associations" of the Alawi state. ${ }^{75}$

At the start of the Arab Spring at least, demands by protestors on King Abdullah were consistent with those made on M6; namely, constitutional reforms restricting the king's control over parliament and reduction of economic disparity between rich and poor. What was noticeably different in the Jordanian Spring was greater levels of protest in the traditional stronghold of monarchical support - the "Transjordan areas." "76

Distributions of wealth during Jordan's during the Arab Spring are telling as with the Moroccan case study. Jordan's economy has traditionally relied on healthy international subsidies. First, from Great Britain during the Kingdom's formative years; second from the IMF to support economic restructuring; and third, from the U.S. which has bolstered the Hashemite Kingdom with up to nearly a quarter billion dollars from 1998 to 2002, close to 1 billion in 2003 with the start of the Iraq War, and about 3/4 billion every year since then. ${ }^{77}$ Iraq had long been Jordan's largest trading partner. The U.S. incursion into Baghdad also resulted in a mass exodus of refugees into Iraq's western neighbor. With a more or less friendly foreign policy towards Israel, the U.S. has always sought to bolster the stability of the Hashemite Kingdom. To wit, \$200 million of U.S. annual aid goes directly to Jordan's military and security services. ${ }^{78}$ Jordan's GDP has grown as much as $6 \%$ per annum in recent years, but this has largely been predicate upon banking and real estate sectors. Despite substantial foreign aid and a relatively small

\footnotetext{
75 (Henry 2014, 138)

76 (Yaghi 2014, 236)

77 (Brand 2011, 499)

${ }^{78}$ Ibid.
} 
population of about 6.5 million citizens, Jordan's lack of natural resources and dearth of manufacturing continues to plague the state's economic forecast.

In contemplation of normative distributions in Jordan, it is tempting to hypothesize that Morocco's monarchy, given its much longer reign, might command greater popular allegiance than Jordan's, garnered from a longer history of institution building or even just simple reverence for the monarchy. One way to test this idea is to compare the demands of protestors. While regime opposition in Morocco almost entirely avoided direct criticism of the king, Jordanian protestors were more brazenly antimonarch at times with chants such as "Hey Abdullah, the son of Hussein: Where is the people's money?" and "Ali Baba and the forty thieves," comparing King Abdullah, and family, to a criminal ring-leader and his gang. ${ }^{79}$ Recall from the previous section, that these chants often occurred in Transjordan strongholds of monarchical support. This gives some credence to the idea that King Abdullah does not enjoy the level of traditional and religious legitimacy of his Western sharifian cousin.

Like Morocco, the King of Jordan has historically used the power of decree to outlaw public criticism of the monarchy. ${ }^{80}$ During the Arab Spring, however, criticism emanated from groups other than just isolated bands of youthful urban protestors. Tribal leaders known as the "36 Current" attacked the very historical narrative underpinning the king's legitimacy in an open letter to the king reminding him that it was they, the true Transjordans, who took in the king's family as impoverished guests. ${ }^{81}$ It is apparent that

\footnotetext{
79 (Yaghi 2014, 246)

${ }^{80}$ Ibid., 247 Quoting Ellen Lust's research, notes that King Hussein prosecuted violators of the Press and Publications Law sixty-six times during 1990s.

${ }^{81}$ Ibid., 249
} 
King Abdullah II of Jordan has been unable to capture and dominate the public media sphere as effectively as Morocco's Makhzan.

Reflection on these two linchpin monarchies during the Arab Spring provides insight. What is striking about this comparison, given their vastly different histories, is the levelling effect colonial intervention has had on these two institutionally similar states. Jordan is fundamentally a joint venture in state creation between a British regent and a sharif from Mecca in the first half of the $20^{\text {th }}$ century. Morocco is a far older, geographically varied, demographically disparate plurality, whose political ascendance into modernity was guided and strengthened by the French resident-general.

Nevertheless, both countries resemble one another in their struggle to assimilate various identity groups using an institutional style which allows non-family members to head various governmental departments. They both are seen by Western countries as more liberal and stable than their Arab contemporaries. Both states promote a version of Islam which tends to be less patriarchal than in the GCC states and economies which are more inclusive of women. Moreover, they both survived the Arab Spring more or less intact.

However, lacking the historic economic and social ties which binds Moroccan society, it is possible to see how Jordan's legitimacy narrative lacks veracity in the eyes of many of its people. It is the intertwining of narrative, economics, and social networks which gives the Makhzan its strength. That is clearly lacking in the Jordanian case. Despite their superficial similarities, Jordan's monarchy necessarily depends on higher levels of external rents to sustain its regime than does Morocco's. It is a structurally more vulnerable state. But this vulnerability may, perhaps make it more susceptible to 
democratic change, especially if given the proper support and encouragement by Western powers.

\section{Does monarchy matter?}

The findings from this analysis suggest monarchy does matter, but only as one component of a complete authoritarian system. Particularly in the linchpin MENA states in the case of the Arab Spring, this particular political structure gave latitude to Abdullah II and Mohammed VI to not only rhetorically respond to opposition demands but to back up their promises for reform with institutional action. As opposed to the republics where institutional options were more limited, monarchies in the MENA possess an additional entree on the menu of authoritarianism. Unlike the GCC monarchies, Morocco and Jordan relied much more on their ability to "produce results" in the guise of electoral reform as they both lack the natural resources and economic capital of the Gulf monarchies with which to placate their polities. Dependence on hydrocarbons is demonstrably, a potential hindrance to political development. It depends on the choices made by those in power. ${ }^{82}$

Political scientists, in contrast to those in the "hard" sciences, lack the ability to design and manipulate experiments from which to derive definitive observational conclusions. The Arab Spring, though lacking intentional scientific design, has deductive merit: a set of artificially designed political units (MENA states) with largely imposed political structures, have revealed what appears to be an empirically relevant result. Unlike physics and chemistry, the intervening variables in this "social experiment" are

${ }^{82}$ Consider Norway, a petroleum state, which has avoided the "resource curse" through effective investment of its gains. Qatar exemplifies a MENA oil state which has diversified extensively. 
many. Nevertheless, the results are hard to entirely dismiss. Another issue with the royal vs. republic debate, as previously discussed, is properly conceptualizing exactly what a monarchy is and how they are functionally different.

From this analysis at least, one conjecture is that linchpin monarchies possess political economies which serve both to absorb social frustration and transform it into political openings better than dynastic monarchies. The latter, in contrast, owe the preponderance of their legitimacy to their wealth and have generally chosen not to increase their distributions of decision-making power. ${ }^{83}$ They are simply not forced to open political space to the same degree as the monetarily poorer linchpins.

Analysis on regime type in the Arab Spring lacks empirical rigor. There simply aren't enough cases to make the results statistically significant. Where researchers incorporate all MENA monarchies into the analysis (Lucas) they are unable to exclude intervening regional variables sufficiently. Libya and Algeria have been un-exceptional during the Arab Spring - both would have likely survived (embattled as Qaddafi was) largely due to the regime security that oil buys; the former an oil-rich state whose leader perished largely because of external Western intervention while the latter petro-state's leadership persevered without any significant outside influence. Bahrain remains an interesting outlier among GCC monarchies; an oil-rich yet sectarian-divided state saved from internal strife by Saudi security forces. Oil and outside intervention by powerful militaries both have critical effects on the continuity of leadership in embattled states. But states where the regime is represented by a religious minority (Bahrain and Syria) face

${ }^{83}$ Kuwait is the lone GCC exception. 
daunting challenges to internal order. It is nearly impossible to disambiguate the independent effects within these cases with precision.

Lisa Anderson believes that monarchy has been an effective state-building institution in the MENA. The tide is turning toward more open political systems, though not as quickly as most would like. Democracy need not mirror the values of Western society, and it can develop within Arab Muslim states as it has in other Muslim majority states and is happening in Tunisia now. In Morocco, monarchy has mattered during the Arab Spring by bolstering an already existing and well-developed patronage system with a hegemonic media apparatus. A newer generation of Arabs is now proving that institutions based on authoritarian models will have an increasingly difficult job of maintaining the status quo in the future.

In short, it is not so much that monarchy matters, but that the degree of concentration of power and the decisions made by powerful actors matters more. It also is apparent that the will of powerful foreign interests can have overwhelming intervening effects regardless of the form of government. This is true historically across all regions. 


\section{Chapter 8}

\section{Implications for U.S. Foreign Policy}

This thesis contends that the Moroccan monarchy survived the Arab Spring by placating elite opposition with promises for reform while avoiding elite rupture by maintaining the status quo power structure. This was accomplished by capitalizing on a legacy of accumulated decision-making power and wealth, and using it to dominate public discourse. This sort of Machiavellianism is not uncommon. However, the style and function of the Moroccan Makhzan, as a subset of Middle East monarchies, exemplifies a unique, path-dependent legacy of colonial intervention into the political, economic and religious sectors of a former protectorate.

Understanding this unique path-dependent trajectory and how it shapes current local politics is paramount to achieving U.S. foreign policy objectives in Morocco and the Middle East. This section reviews how military intervention, military aid, monetary assistance, and diplomatic support have been used in this region and to what effect. The intent is to highlight which means best match intended U.S. national security ends, particularly with respect to Morocco. The main contention here is that U.S. emphasis on combating terrorism often thwarts even our own democracy building projects both in Morocco and in the Middle East. Allocating a much greater percentage of monetary aid on non-military projects will have greater long-term benefits in both reducing terrorism and in building stronger democracies.

The reasons for disparate U.S. bilateral relations among the southern Mediterranean states may be understood by examining American national interests and 
the historic relationships between the U.S., the "Barbary States" with their European neighbors. Libya and Morocco, in particular, demonstrate contemporary relationships which clearly resonate from America's inception. The Barbary Wars, beginning in 1801, resulted from commercial shipping disputes between the newly independent United States and the Ottoman controlled "city-states" of Tunis, Algiers, and Tripoli as well as the independent Sultanate of Morocco. These battles led to the consecration of the U.S. Navy and the first U.S. foreign land skirmish in Tripoli.

Over 200 years later, and after several incursions, the U.S. and NATO helped put an end to one of the region's most notorious despots - Muammar Qaddafi. Though wellintentioned, as all incursions purport to be, the backlash of U.S. foreign policy in Libya at the start of the Arab Spring has resulted in a domestic situation more volatile than the heavy-handed rule of the Brother Colonel. The NATO-led intervention in Libya's 2011 power struggle left this institutionally destitute country primed for anarchy. Da'ish (ISIL) quickly made the most of this opportunity by filling in the political void following the death of Qaddafi and has used the state's oil and weaponized youth to do its bidding. This is only the latest chapter in America's foreign relations on the Mediterranean south littoral.

At the entrance to the Mediterranean is the first state to recognize U.S. independence. Morocco began building an alliance with the future super-power in 1777, even as Britain's recently detached colony began its initial projection of naval strength two states over. This relationship has continued relatively unabated ever since. European/Moroccan relations are a different matter however. During the $20^{\text {th }}$ century, the northwest corner of Africa has hosted two colonizing regimes simultaneously (France 
and Spain) while others, namely, Germany and Britain, also made power plays over strategically important points. Ceuta is a prominent Spanish owned enclave in Morocco which is kept as counter-weight to the British-held enclave of Gibraltar. Both are strategic land overlooks of the entrance to the Mediterranean which have been fought over for centuries. The political intrigue between Spain and Morocco over its continued possession of numerous enclaves is as troublesome for the Moroccan monarchy as Britain's continued possession of Gibraltar is for Spain.

Other U.S. relationships along the North African littoral are also useful in grappling with modern political science concerns. U.S. relations with Algeria, a hydrocarbon-rich state, tend to resemble the strained relationship between the U.S. and Libya. Like Libya, Algeria not only has abundant fossil fuel, but it has a history of experimentation with socialism and alliances with states on the opposing side of the U.S. during the Cold War. Tunisia, in contrast, turned toward economic structural adjustment and free-market reforms relatively early. Though not traditionally linked to the U.S. in significant ways, this smallest of the Maghreb states has close economic ties with France first and other European countries second.

A quick tally reveals that Maghreb states with hydrocarbons (Libya and Algeria) appear to fare the worst for peace/stability while those lacking them (Tunisia and Morocco) seem to fare better. Clearly, while fossil fuels cannot be entirely to blame for regional instability, this result corroborates the legacy of Western intervention into other MENA states, such as Iran and Iraq. What can be said is that hydrocarbons make a given territory very attractive to both external and internal interests. Managing those competing interests makes a ruler's job both easier and more complex: Harder to obtain control over 
initially, but perhaps easier in that once control is had over an oil-rich territory, the rents obtained help immensely to bolster that regime. And again, diversifying an oil-dependent economy and beating the "resource curse," as the modernization programs of the GCC states and Iran can testify, is altogether another challenge.

Democracy building is a featured tenant of U.S foreign policy. Strong democracies are key to building a stable, reliable community of states says the Department of State website. Well regarded scholarship lends credence to the effectiveness of popular representation in government. ${ }^{84}$ Implementing foreign support which fosters the growth of the institution is another matter. Democracy building through limited military intervention, economic aid or sanctions, and diplomacy were the main tools for achieving this foreign policy objective well into the 1990s. After the turn of the century, and an alternation in U.S. power, the 9/11 attacks on U.S. soil asserted Middle East terrorism, seemingly, as an existential threat. The foreign policy objectives turned from neo-liberal reforms to regime change.

This essay refutes the notion that foreign-led regime change fosters democracy or bolsters U.S. national security interests. For one, Tunisia started the Arab Spring. And as noted, it was almost certainly lowest on the U.S. radar of influence - either for assistance or for regime change. Its economic ties with Europe were many and its security ties with the U.S. have been very low, historically speaking. That did change somewhat after 9/11 when the U.S began in earnest to halt the alleged spread of international terrorism in to North Africa with the creation of AFRICOM on the military side, and through several

${ }^{84}$ (Przeworski 2000) 
economic assistance packages such as MEPI. Tunisia has had the least economic or military intervention from the U.S. and is currently the only democracy in North Africa.

U.S. military interventions in the Middle East have proven baleful for both domestic Arab populations and the American economy. It was the U.S. legacy of intervention in Afghanistan against the USSR which strengthened the opposition Mujahidin, led by Osama Bin Laden, who would later form the terrorist group Al Qaeda. The 2003 invasion of Iraq was purported to be an extension of the GWOT, despite Saddam Hussein having no demonstrable ties to Al Qaeda. Nevertheless, actors within the Bush regime were adamant he must be removed. The ensuing invasion and Paul Bremer's decision to fire all Ba'athist members (including the Iraqi army and police) let loose a wave of virtually uncontainable social forces which have played a large role in the creation of Da'ish today. No, the U.S. didn't "start the fire" but considerable hydrocarbon resources certainly did help make it a conflagration. Poor planning, lack of historical and institutional awareness, and arguably, vested interest in oil futures all played a part in this last incredible fiasco.

American military aid and direct intervention in Afghanistan, Iraq, and Libya are only three cases where ambiguous U.S. foreign policy objectives and haphazard interventions led to incursions which favored a minority of special interests while overwhelmingly resulting in a massive loss of lives and taxpayer dollars ${ }^{85}$ It would be incomplete to place the impotence of Middle East intervention solely on the U.S. government. In a study of U.N. backed interventions during the 1990s, Ottoway and Lacina found, "international interventions have had a surprisingly limited ability to bring

${ }^{85}$ (Bacevich 2016; Khalidi 2004) 
positive transformation to targeted countries, a dilemma that U.S. unilateralist interventions are likely only to aggravate." Knowing what is best for a foreign government, who viable domestic partners are, and how to implement support have all proven to be extremely difficult tasks, even for those who possess significant regional knowledge.

So what about the Morocco's Arab Spring and U.S. reaction to it? Accolades by U.S. politicians and pundits to M6's constitutional reforms in 2011 are telling. ${ }^{86}$ The message they sent may be interpreted as the U.S. giving positive reinforcement to a MENA regime more closely aligned with American electoral institutions and possessing a free-market economy.

Alternatively, the U.S. is also seen to be overplaying support for a moderately strategic, and still repressive, ally.

It is sometimes difficult to interpret the intentions of official, or non-official, pronouncements. Leaders often give mixed messages for a variety of reasons. U.S. leaders will continue to promote liberal values where they see them in the Arab world. They will simultaneously seek to bolster the economic interests of the actors who they perceive are most likely to be useful to them politically. American economic and military interests typically mute any rhetorical backlash when allied states like Saudi Arabia and Bahrain use repression against their citizens. The reason for this encompasses vested economic interests in oil and gas but it is also the result of the deepening strategic partnership between the U.S and Israel.

${ }^{86}$ Hillary Clinton and Jesse Jackson were two (among many) who made note of the king's liberal reforms and congratulated him for his ability to promote democracy and stability. 
Morocco has long been home to one of the world's most vibrant Jewish populations, at least until recent decades when Hassan II sided with Palestinians after 1967 to avoid losing domestic legitimacy. Even so, Morocco continued to play the role of arbiter in Arab-Israeli talks which has ingratiated the king to U.S. presidents. Following 9/11, Morocco joined virtually every other Arab state (even Iran attempted to do so) in joining the anti-terrorist movement.

Obtaining access to U.S. security assistance funds was a key motivation to join the GWOT. Jordan, as discussed, secured hundreds of billions of regime sustaining US dollars, as well as military upgrades, from this assistance. Both Morocco and Jordan reflect two of the key pillars of being a MENA member of the post-9/11 US security alliance: being pro-Israel and anti-terror. These two things have actually become mutually exclusive in the dominant US public discourse even more so than in Israeli media where a more nuanced perspective is taken to the matter. The message has in effect become such that being at all anti-Israel foreign policy means you actually support terrorism. Arab leaders have learned this lesson. In particular, Morocco's monarchs have worked diligently to portray themselves as moderate and pro-peace. In 1986, Hassan II became only the second Arab leader to host an Israel leader (Shimon Perez) for talks.

So what helps to bolster democracy in North Africa? Recall the critique put forward in the literature review that international aid in the MENA has had two important consequences: it lowers the cost of domestic repression by diminishing international backlash and it arms domestic regimes with greater coercive means. This combination of financially assisted autocratic coercion and then ignoring subsequent abuse of that authority represents the potential blowback of foreign aid in the Middle East. Tunisia has 
had relatively little military aid historically. A president distanced from his military apparatus was also advantageous to Ben Ali's opposition.

Consider that Saudi Arabia, by example, is the U.S.'s favored Arab trading partner. This theocratic state continues to outsource some of the most dangerous terrorists in the world. U.S. politicians are not unaware of this situation. As long as special interests are given special entrée into the American political system, it is unlikely that this dynamic (saying one thing and funding the complete opposite) will change. This is not the only country the U.S. supports which also possesses inherently antithetically democratic values. Bahrain has based the U.S. $5^{\text {th }}$ Naval fleet for decades. The base was installed during the Carter administration to counter Iran in the Persian Gulf after its revolution in 1979.

U.S. military and monetary aid provides other mechanisms for promotion of U.S. national interests which demonstrate the unfortunate backlash of unintended consequences in the MENA. The bilateral relationship between the U.S. and Israel is notable. Unflagging American support for the "Jewish state," a state which has been in violation of UN resolutions barring settlement of Palestine occupied territories since 1969, perpetuates not only a burgeoning and unsustainable "Apartheid regime," but increasingly diminishes American prestige in the eyes of Arabs and our European allies. If the U.S. truly wishes to enhance democratic outcomes in MENA states, more aid should be conditionally allocated to non-military strengthening projects. It is in fact the aid which U.S. has given to unpopular leaders over decades which has helped entrench them and create resentment against the U.S. Doubling down with greater aid to regimes to fight terrorism serves to exacerbate this resentment. 
These cases demonstrate that achieving U.S. foreign policy goals through military intervention in the Middle East is proving ineffective. Morocco rests on the periphery of what Andrew Bacevich calls the America's War for the Greater Middle East ${ }^{87}$ While the Carter Doctrine once secured U.S. access to the Persian Gulf energy channel, the benefits of funding and maintaining such a high level of securitization in this region have become unclear. This is especially true as development of alternate sites and sources of energy accelerates. The states of the classic Maghreb (Morocco, Algeria, and Tunisia) are geographically further from Israel and the Persian Gulf, and have received relatively less attention from the U.S. than their former colonial ruler, France. It is therefore interesting to note that these three states have demonstrated some of the greatest political attempts at shifting toward democratic models in the Middle East. Recent American incursions in the MENA have cost the average American taxpayer dearly, and profited only a select few. Our security partners' leadership (i.e., Morocco and Jordan) benefit similarly from U.S. military aid. Offering more non-military aid packages, and attaching more conditions to that aid, can better facilitate democratization. Military aid often subsidizes the repressive security apparatus in these countries.

U.S. national interests in North Africa seek to stabilize friendly regimes and remove unfriendly ones. Throughout the Middle East, U.S. national interests have revolved around three main pillars: ensuring access to oil around the Persian Gulf, support for the GWOT, and strategic support for Israel. Economic aid and diplomatic support allocated toward individual MENA states is typically apportioned with respect to these aims. Hence, the littoral states of the Persian Gulf enjoy immensely subsidized

${ }^{87}$ (Bacevich 2016) 
protection at the expense of the U.S. taxpayer. Jordan and Egypt receive tremendous monetary aid and security assistance given their proximity to Israel. Egypt receives additional U.S. attention as it controls the Suez Canal.

Lacking hydrocarbons and proximity to Israel or the Persian Gulf, most Maghreb states arouse U.S. concern for the terrorist activities which emanate from their territories. Libya is the best example of negative U.S. attention. Algeria is the hydrocarbon exception of this group and it is also an exceptional case as a republican regime which survived the Arab Spring. While democracy promotion remains a priority of the U.S. Department of State, the Department of Defense missions encompassing counterterrorism operations and security assistance receive immensely more funds. The benefits of these investments are becoming increasingly more costly in blood and treasure. U.S. reliance on petroleum is especially concerning considering the disastrous potential of climate change on this already arid region. As the MENA becomes increasingly distressed by heat and weakened agriculture production, the cost to the U.S. in maintaining stability will grow precipitously. Moving away from hydrocarbons as a primary energy source is clearly in the U.S. national interest with a corresponding decrease in U.S. military presence in the Middle East.

As dependence on oil decreases, the nearly unconditional support given to Israel may also decrease in time. This relationship has lost a great deal of its utility to the U.S. national interest, particularly as the Likud government has all but completely made clear its intention to prohibit Palestine from ever becoming an autonomous state. Benjamin Netanyahu has said as much. Favoritism of the so-called "Jewish State" especially given Israel's development toward apartheid, should give U.S. stakeholders in democracy cause 
for alarm. Even in Morocco, a schism exists between the ruling regime which must hedge its diplomatic critiques of Israel as Moroccan citizens privately fume at what many consider to be an assault on their religion. Resentment against unconditional U.S. support for Israel will certainly rise, especially given recent increases in U.S. annual aid to it, even as Likud publicly rebukes the U.S. president. Shortsighted policies in the Middle East over the last several decades have caused tremendous blowback by increasing costs to the average U.S. taxpayer, and creating resentment among Arab populations against the U.S., which in turn, has helped the recruitment efforts of anti-U.S. terror groups. Refocusing U.S. monetary aid on non-military projects will have greater long-term benefits in both reducing terrorism and in building stronger democracies. 


\section{Chapter 9}

\section{Conclusion}

The argument put forward and defended in this thesis is that the Makhzan survived the Arab Spring largely by the manufacture of consent whose mechanisms include: controlling public discourse through both coercive and non-coercive mechanisms; using this propaganda monopoly to take advantage of a broad, but arguably temporal, preference for stability and desire for gradual democratic transition in a time of regional unrest; and using this elevated platform to continuously, and largely semantically, re-invent itself as the sole, legitimate provider of public goods. Being a hereditary monarchy appears to offer a regime some resiliency, but what clearly matters more is concentrated power and wealth, a deep and broad domestic support base, and a foreign policy which is not generally at odds with major international powers.

The Alawi regime has stood the test of time for several reasons: It is a historically entrenched, Western backed regime whose current dynastic leader is generally perceived as favorable for being both a symbol of national unity and a gradual reformist. He is neither the authoritarian his father was nor is he radically progressive enough to disenfranchise his elite clients which might create a disastrous factional split. For over four centuries, the Moroccan monarchy has persisted and increased its degree of control. Since Moroccan independence in 1956 the regime has survived due to adroit (and sometimes ruthless) leadership, the acquiescence of more powerful regional actors, and by sheer chance. During the Arab Spring of 2011, it used its amassed power and wealth to saturate the public sphere with its narrative of historic legitimacy and will to reform. 
The future success of the monarchy depends largely on how well it continues to employ this system of manufactured consent. 


\section{Bibliography}

AlamiI, Aida. 2014. Rebel Prince Shines a Harsh Light on Morocco. May 9. Accessed October 2, 2015. http://www.nytimes.com/2014/05/10/world/africa/moroccos-rebelprince.html?_r=0.

Anderson, Benedict R. O'G., and American Council of Learned Societies. 2006. Imagined Communities Reflections on the Origin and Spread of Nationalism. Rev. ed. London; New York: Verso.

Anderson, Lisa. Spring, 1991. "Absolutism and the Resiliency of Monarchy in the Middle East." Political Science Quarterly 1-15.

Anderson, Lisa. 2000. "Dynasts and Nationalists: Why Monarchies Survive." In Middle East Monarchies, by Kostiner, 53-69. Boulder: Lynne Riener Publishers.

Anderson, Lisa. 1991. "Legitimacy, Identity, and the Writing of History in Libya." In Statecraft in the Middle East: Oil, Historical Memory, and Popular Culture, by Eric, Gavrielides, Nicolas E, and Joint Committee on the Near Middle East Davis, 71-91. Miami, FL: Florida International University Press.

—. 1986. The State and Social Transformation in Tunisia and Libya:1830-1980. Princeton: Princeton University Press.

Antonius, George. 1965. The Arab Awakening: the Story of the Arab National Movement. Capricorn Books.

Aslan, Reza. 2005. No God but God: The Origins, Evolution, and Future of Islam. New York, NY: Random House.

Bacevich, Andrew J. 2016. America's War for the Greater Middle East. New York: Random House.

Bank, André, Thomas Richter, and Anna Sunik. 2014. "Durable, Yet Different: Monarchies in the Arab Spring." Journal of Arabian Studies 163-79.

Bank, Andrr, Thomas Richter, and Anna Sunik. 2013. "Long-Term Monarchical Survival in the Middle East: A Configurational Comparison, 1945-2012." Democratization SSRN Electronic Journal SSRN Journal. .

BBC Africa. 2011. Morocco's King Mohammed unveils constitutional reforms. 6 18. Accessed 3 20, 2016. http://www.bbc.com/news/world-africa-13816974.

Bellin, Eva. 2012. "Reconsidering the Robustness of Authoritarianism in the Middle East: Lessons from the Arab Spring." Comparative Politics 127-49. 
Benchemsi, Ahmed. 2014. "Morocco's Makhzen and the Haphazard Activists." In Taking to the Streets, by Lina and Lust, Ellen Khatib, 199-235. Baltimore: Johns Hopkins University Press.

Benchesmi, Ahmed. 2011. Morocco and Press Freedom: It's Complicated. 9 10. Accessed 49 , 2016. http://ahmedbenchemsi.com/morocco-and-press-freedom-a-complicatedrelashionship/.

Benstead, Lindsay J. 2014. "Why Do Some Arab Citizens See Democracy as Unsuitable for Their Country?" Democratization 1-26.

Bloomberg. 2010. Phosphate: Morocco's White Gold. 11 4. Accessed 4 10, 2016.

http://www.bloomberg.com/news/articles/2010-11-04/phosphate-moroccos-white-gold.

Brand, Laurie A. 2011. "Jordan." In The Middle East, by Ellen Lust, 486-510. Washington DC: CQ Press.

Burgat, François, and Dowell, William. 1993. The Islamic Movement in North Africa. Austin, TX: Center for Middle Eastern Studies, University of Texas at Austin.

Burke, Edmund. 2014. The Ethnographic State: France and the Invention of Moroccan Islam. Oakland, CA: University of California Press.

Carr, Edward Hallett. 1946. The Twenty Years' Crisis, 1919-1939: An Introduction to the Study of International Relations. London, UK: Macmillan.

Chomsky, Edward S. Herman \& Noam. 1988. Manufacturing Consent: The Political Economy of the Mass Media. New York: Pantheon Books.

Cizakca, Murat. 2000. A History of Philanthropic Foundations: The Islamic World From the Seventh Century to the Present. Istanbul: Bogazici University Press.

Curtis, Michael. 1961. The Great Political Theories. New York: Avon Book Division.

Daadaoui, Mohamed. 2011. Moroccan Monarchy and the Islamist Challenge: Maintaining Makhzen Power. New York : Palgrave Macmillan.

Dahl, Robert A. 1971. Polyarchy; Participation and Opposition. New Haven,CT: Yale University Press.

Derichs, Claudia, and Thomas Demmelhuber. 2014. "Monarchies and Republics, State and Regime, Durability and Fragility in View of the Arab Spring." Journal of Arabian Studies (Journal of Arabian Studies) 180-94.

Gausse, F Gregory. 2013. Kings for all seasons. Analysis Paper, Washington D.C.: Brookings Doha Center. 
Hamid, Anouar Boukhars and Shadi. 2011. Morocco's Moment of Reform? . June 28. Accessed October 2, 2015. http://www.brookings.edu/research/opinions/2011/06/28-moroccohamid-boukhars.

Hammoud, Hassan. 2005. "Illiteracy in the Arab World." Beirut.

Hammoudi, Abdellah. 1997. Master and Disciple: The Cultural Foundations of Moroccan Authorianism. Chicago: The University of Chicago Press.

Hannoum, Abdelmajid. 2015. "Book review: The Ethnographic State: France and the Invention of Morrocan Islam." Journal of North African Studies 896-898.

Hedges, Chris. 2016. The Revenge of the Lower Classes and the Rise of American Fascism. 32. Accessed 4 16, 2016. http://www.truthdig.com/report/item/the_revenge_of_the_lower_classes_and_the_rise_of _american_fascism_20160302.

Henry, Clement H. 2014. "States and Bankers." In The Arab Uprisings Explained, by Mark Lynch, 127-141. New York: Columbia University Press.

Herb, Michael. 2013. "Institutions and zeitgeist: regime type and the pattern of protests in the Arab Spring." Presentation at the Project on Middle Eastern Political Science. Georgia State University.

Herb, Michael. 2004. "Princes and Parliaments in the Arab World." Middle East Journal ( Middle East Journal 58, no. 3 (2004): 367-84.) 367-84.

Herman, Edward S., and Chomsky, Noam. 1988. Manufacturing Consent: The Political Economy of the Mass Media. New York, NY: Pantheon Books.

Hibou, Beatrice. 2011. The Force of Obedience: The Political Economy of Repression in Tunisia. English ed. Cambridge, MA: Cambridge: Polity Press.

Hicham, Moulay, interview by Stephen Smith. 2012. Arab Spring: An Interview with Moulay Hicham

Hicham, Moulay, interview by France 24 reporter. 2011. http://www.france24.com/en/20110217en-interview-prince-moulay-hicham-el-alaoui-mohammed-vi-morocco-democracytransition-stanford-fellow (Feb 21). Accessed October. http://www.france24.com/en/20110217-en-interview-prince-moulay-hicham-el-alaouimohammed-vi-morocco-democracy-transition-stanford-fellow/.

Huntington, Samuel P. 2006. Center for International Affairs. Political Order in Changing Societies. New Haven \& London: Yale University Press. 
Jamal, Amaney, and Mark Tessler. 2008. "Attitutudes in the Arab World." Journal of Democracy 97-110.

Jenkins, Craig T., et al. 2011. "International Rentierism in the Middle East and North Africa, 1971-2008." International Area Studies Review Vol 14, Number 3.

Khaldoun, Abou Zaid, and Franz Rosenthal. 1967. The Muqaddimah: An Introduction to History. Princeton: University Press.

Khalidi, Rashid. 2004. Resurrecting Empire: Western Footprints and America's Perilous Path in the Middle East. Boston, MA: Beacon Press.

Khatib, Lina and Lust,Ellen. 2014. Taking to the Streets. Baltimore: Johns Hopkins University Press.

Kilani, Ibrahim Zeid. 1986. "The Place of Al-Qods in Islam." In The Hassanian Lectures, by The Ministry of Waqfs and Religious Affairs, 199-200. The Ministry of Waqfs and Religious Affairs.

King, Stephen J. 2003. Liberalization Against Democracy The Local Politics of Economic Reform in Tunisia. Indiana Series in Middle East Studies. Bloomington, IN: Indiana University Press.

King, Stephen Juan. 2009. New Authoritarianism in the Middle East and North Africa. Bloomington, IN: Indiana University Press.

Kostiner, Joseph, ed. 2000. Middle East Monarchies: The Challenge of Modernity. Boulder: Lynne Rienner Publishers.

Kuhn, Thomas. 1996. The Structure of Scientific Revolutions. Chicago: THe University of Chicago Press.

Lalama, Laila. 2011. "The Moroccan 'Exception'." The Nation. September 12. Accessed October 5, 2015. http://www.thenation.com/article/moroccan-exception/.

Larbi. 2012. J'ai vu condamner des innocents. September 12. Accessed October 2, 2015. http://www.larbi.org/post/2012/09/J-ai-vu-Condamner-des-innocents.

Leveau, Remy. 2000. "The Moroccan Monarchy: A Political System in Quest of a New Equilibrium." In Middle East Monarchies, by Joseph Kostiner, 117-130. Boulder: Lynne Rienner Publishers, Inc.

Lucas, Russell E. 2014. "Monarchies and Protests in the Arab Uprisings: Path Dependencies or Political Opportunities? ." Journal of Arabian Studies 195-213.

Lust, Ellen. 2011. The Middle East, ed. 12th ed. Washington, D.C.: CQ Press. 
Lynch, Marc. 2012. The Arab Uprising: The Unfinished Revolutions of the New Middle East. New York, NY: PublicAffairs.

Lynch, Marc, ed. 2014. The Arab Uprisings Explained: New Contentious Politics in the Middle East. New York, NY: Columbia University Press.

Macnamara, Jim. 2005. "Media content analysis: Its uses; benefits and best practice methodology ." Asia Pacific Public Relations Journal 1-34.

Malka, Haim and Alterman, Jon. 2006. Arab Reform and Foreign Aid. Washington DC: The CSIS Press.

McLean, Iain, and Alistair McMillan. 2003. Oxford Concise Dictionary of Politics. Oford: Oxford University Press.

McLean, Iain, and McMillan, Alistair. 2009. The Concise Oxford Dictionary of Politics. New York, NY: Oxford University Press.

Memmi, Albert. 1991. The Colonizer and the Colonized. New York: Orion Press.

Memmi, Albert, and Robert Bononno. 2006. Decolonization and the Decolonized. Minneapolis: University of Minnesota Press.

Menaldo, Victor. 2012. "The Middle East and North Africa's Resilient Monarchs." The Journal of Politics 707-722.

Miller, Susan Gilson. 2013. A History of Modern Morocco. New York: Cambridge University Press.

Muasher, Marwan. 2014. The Second Arab Awakening: And the Battle for Pluralism. New Haven: Yale University Press.

National Geographic. 2008. Atlas of the Middle East. Washington, D.C.: the National Geographic Society.

Nonneman, Gerd. 2001. "Rentiers and Autocrats, Monarchs and Democrats, State and Society: The Middle East between Globalization, Human "Agency", and Europe." International Affairs (Royal Institute of International Affairs 1944-) 141-62.

Perkins, Kenneth J. 2004. A History of Modern Tunisia. New York: Cambridge University Press.

Pike, John. 2006. Moroccan Economic Sectors. 4 10. Accessed 4 10, 2016. http://www.globalsecurity.org/military/world/morocco/economy-sectors.htm.

Przeworski, Adam. 2000. Democracy and Development: Political Institutions and Well-being in the World, 1950-1990. Cambridge: Cambridge University Press. 
Ross, Michael L. 2008. "Oil, Islam, and Women." American Political Science Review 107-123.

Ruedy, John. 2005. Modern Algeria: The Origins and Development of a Nation . Bloomington: Indiana University Press.

Russell, Bertrand. 1938. Power: A New Social Analysis. London: George Allen \& Unwin LTD.

Schedler, Andreas, ed. 2006. Electoral Authoritarianism: The Dynamics of Unfree Competition. London: Lynne Rienner Publishers.

Skocpol, Theda. 1979. States and Social Revolutions: A Comparative Analysis of France, Russia, and China. New York: Cambridge Univesity Press.

Spiegel, Avi. 2013. Fear and Loathing in Morocco. 9 27. Accessed 4 2, 2016. http://foreignpolicy.com/2011/12/05/moroccos-islamist-prime-minister/.

Spruyt, Hendrik. 1994. The Sovereign State and Its Competitors: An Analysis of Systems Change. Princeton, N.J.: Princeton University Press.

Taylor, Charles. 1985. Philosophy and the Human Sciences. Cambridge: Cambridge University Press.

Tessler, Mark and Benstead, Lindsay. 2011. Why are Some Ordinary Citizens in Partly-Free Countries 'Security Democrats?' Insights from a Comparison of Morocco and Algeria . Unpublished.

Voll, John O. 1997. "Sultans, Saints, and Presidents: The Islamic Community and the State in North Africa." In Islam, Democracy, and the State in North Africa, by John P. Entelis, 116. Bloomington and Indianapolis: Indiana University Press.

Waltz, Susan Eileen. 1995. Human Rights and Reform: Changing the Face of North African Politics. Berkeley: University of California Press.

Waterbury, John. 1970. The Commander of the Faithful: The Moroccan Political Elite - a Study in Segmented Politics. New York: Columbia University Press.

White, Gregory. 2001. A Comparative Political Economy of Tunisia and Morocco: On the outside of Europe Looking in. New York: State University of New York Press.

Willis, Michael J. 2012. Politics and Power in the Maghreb: Algeria, Tunisia and Morocco from Independence to the Arab Spring. New York: Columbia University Press.

Yaghi, Mohammed and Clark, Janine. 2014. "Jordan." In Taking to the Streets, by Lina Khatib and Ellen Lust, 236-267. Baltimore: Johns Hopkins University Press.

Yom, Sean L. 2016. From Resilience to Revolution: How Foreign Interventions Destabilize the Middle East. New York: Columbia University Press. 
Yom, Sean, and Gregory Gause. 2012. "Resilient Royals: How Arab Monarchies Hang On." Journal of Democracy 74-88.

Zartman, I. William, ed. 1987. The Political Economy of Morocco. New York: Praeger Publishers. 
Appendix A

Interview Questionnaire

\section{Explanation:}

I am a graduate student from Portland State University in the U.S., conducting a study on the nature of Morocco's political stability. Your thoughts are very important to me. Please be as expansive as you like in responding. This interview should not take more than 30 minutes to an hour of your time. Be assured that your identity will remain anonymous. Do you have any questions or concerns before we begin?

Questions:

1. What are the most important problems facing Morocco today?

2. How do you explain the stability of Morocco over the last two years in comparison to other Arab states? What role has religion, political institutions, education, economy played?

3. Who is most responsible for the condition of the Moroccan economy?

4. Who are the biggest regime supporters outside of the country? Inside?

5. What state, other than Morocco, do you admire most? Why?

6. What changes would you most like to see in the Moroccan government?

7. What are your thoughts on Morocco's new constitution? Have its promises been fulfilled? What is the meaning of changing the King's status from sacred to inviolable?

8. What is your opinion of student protestors? The February $20^{\text {th }}$ movement?

9. Is the government fostering democratic change? How?

10. Demographic questions: Sex, age, occupation, level of education, city of residence 
Appendix B

Media Content Analysis Data (Discourse Analysis)

$\begin{array}{lr}\text { Akhbar Al-yoom (13 papers) } & \\ \text { Pro-king pics: } & 18 \\ \text { Anti-king pics: } & 0 \\ \text { Pro-king articles: } & 18 \\ \text { Anti-king articles: } & 2 \\ \text { Pro-Ben Kirane pics: } & 3 \\ \text { Pro-Ben Kirane articles: } & 2 \\ \text { Anti-Ben Kirane pics: } & 15 \\ \text { Anti-Ben Kirane articles: } & 35\end{array}$

Al-Akhbar (5 papers)

Pro-king pics: 81

Anti-king pics: 0

Pro-king articles: $\quad 11$

Anti-king articles: 0

Pro-Ben Kirane pics: $\quad 0$

Pro-Ben Kirane articles: $\quad 0$

Anti-Ben Kirane pics: 8

Anti-Ben Kirane articles: 12

Al-Masaa (12 papers)

Pro-king pics: 5

Anti-king pics: 0

Pro-king articles: $\quad 15$

Anti-king articles: 3

Pro-Ben Kirane pics: 4

Pro-Ben Kirane articles: 2

Anti-Ben Kirane pics: $\quad 8$

Anti-Ben Kirane articles: 11 
Appendix B

Media Content Analysis Data (Discourse Analysis)

(Continued)

$\underline{\text { Al'an (1) }}$

Pro-king pics: 0

Anti-king pics: $\quad 0$

Pro-king articles: $\quad 0$

Anti-king articles: $\quad 0$

Pro-Ben Kirane pics: $\quad 0$

Pro-Ben Kirane articles: $\quad 0$

Anti-Ben Kirane pics: 2

Anti-Ben Kirane articles: 3

Total:

Pro-king pics: $\quad 104$

Anti-king pics: 0

Pro-king articles: $\quad 44$

Anti-king articles: 2

Pro-Ben Kirane pics: $\quad 7$

Pro-Ben Kirane articles: $\quad 4$

Anti-Ben Kirane pics: 33

Anti-Ben Kirane articles: 61 